\title{
SEVENTEEN NEW HELICOPSYCHE SPECIES FROM NEW CALEDONIA (TRICHOPTERA,
}

\author{
HELICOPSYCHIDAE)
}

\begin{abstract}
Johanson, K. A., 1999. Seventeen new Helicopsyche from New Caledonia (Trichoptera, Helicopsychidae). - Tijdschrift voor Entomologie 142: 37-64, figs. 1-114. [ISSN 0040-7496]. Published 22 September 1999.

The Helicopsychidae fauna of New Caledonia is revised. Seventeen new Helicopsyche species are described: $H$. arma sp.n., H. baroua sp.n., H. patriciae sp.n., H. fusca sp.n., H. koghiensis sp.n., $H$. livida sp.n., $H$. nigrospinosa sp.n., $H$. ouaroua sp.n., $H$. pellmyri sp.n., $H$. penicilla sp.n., $H$. rossi sp.n., $H$. tenuisa sp.n., $H$. browni sp.n., $H$. neocaledonia sp.n., H. gibbsi sp.n., H. rembai sp.n., and H. unilobata sp.n. A key to the males of the New Caledonian Helicopsyche is provided.

Correspondence: Kjell Arne Johanson, Museum of Zoology, University of Bergen, Muséplass 3, N-5007 Bergen. E-mail: kjell.johanson@zmb.uib.no.

Keywords. - Trichoptera; Helicopsychidae; Helicopsyche; new species; New Caledonia.
\end{abstract}

Twelve Helicopsyche species were previously described from New Caledonia (Johanson \& Schefter 1999, Ross 1975). Ross (1975) described the males of H. edmundsi Ross, 1975, H. petersorum Ross, 1975, $H$. vallonia Ross, 1975, H. starmuehlneri Ross, 1975, H. caledonia Ross, 1975, H. lapidaria Ross, 1975, H. hollowayi Ross, 1975, H. boularia Ross, 1975, H. asymmetrica Ross, 1975, H. kariona Ross, 1975, H. arenaria Ross, 1975 and H. koumaca Ross, 1975. Johanson and Schefter (1999) re-described the males and included descriptions of the female sex, and larval and pupal stages as well. Ross (1975) separated the twelve species into four species groups. The vallonia-group includes $H$. vallonia and $H$. kariona; the edmundsigroup includes $H$. edmundsi, $H$. asymmetrica and $H$. petersorum; the lapidaria-group includes $H$. starmuehlneri, $H$. caledonia, $H$. lapidaria, $H$. boularia and $H$. hollowayi; and finally the arenaria-group includes $H$. koumaca and $H$. arenaria. The phylogenetic significance of this grouping is at present not evaluated.

Johanson (1995, 1997 and 1998) indicated that New Caledonia is among the hot spots in Helicopsychidae, and detection of the species described herein supports the idea of such a hot spot. The aim of this work is to add knowledge to the genus Helicopsyche of New Caledonia.

Type depositories are as follows: Royal Ontario Museum, Ottawa, Canada [ROM], National Museum of Natural History, Smithsonian Institution, Washington D.C., USA [NMNH], Canterbury Museum, New Zealand [CM], Bishop Museum, Hawaii
[BMH] and Ian M. Henderson private collection [IHPC].

\section{DESCRIPTION OF NEW SPECIES}

\section{Helicopsyche pellmyri sp. n.}

(figs. 1-11)

\section{Type material}

Holotype, ${ }^{\star}$ (in alcohol), NEW CALEDONIA: Mt. Koghi, 400m, 12-14.xi.1986, UV trap (R. Brown \& O. Pellmyr) (NMNH).

Paratypes, $15 \hat{\sigma}$ (in alcohol), as holotype; $2 \hat{\sigma}, 1$ 우 (pinned), as holotype; ditto, but $1 \hat{0}$ (pinned), $460 \mathrm{~m}$, 29.xii.1976 (R. E. Dietz IV); $2 \hat{0}, 12$ 우 (in alcohol): Mt. Konanéoa, Les Dalmates, 16640’30”'E, 2212'30”'S, UV trap, 19.x.1986 (R. Brown \& O. Pellmyr) (NMNH); $30 \hat{0}, 2+$ (in alcohol): Col de Mouirange, 210m, 27.x.1986, UV trap (R. Brown \& O. Pellmyr) (NMNH); ditto, but 10, 2 ㅇ (in alcohol), $225 \mathrm{~m} ; 160 \hat{0}, 2$ (in alcohol): $5 \mathrm{~km} \mathrm{~S}$ Touho, $100 \mathrm{~m}$, Panandou River, $165^{\circ} 13^{\prime} \mathrm{E}, 20^{\circ} 49^{\prime} \mathrm{S}, 22-23 . i i .1984$ (M. Pogue \& M. Epstein) (NMNH).

\section{Diagnosis}

Male $H$. pellmyri sp. n. are distinguished from other Helicopsyche species by the anterodorsally produced and edged IXth segment (fig. 3); the about twelve Xth tergal megasetae (figs. 5,7); the strongly mediad curved gonocoxal secondary branches (fig. 6); and the tuboid and slightly laterad angled basomedian branches (fig. 6). 

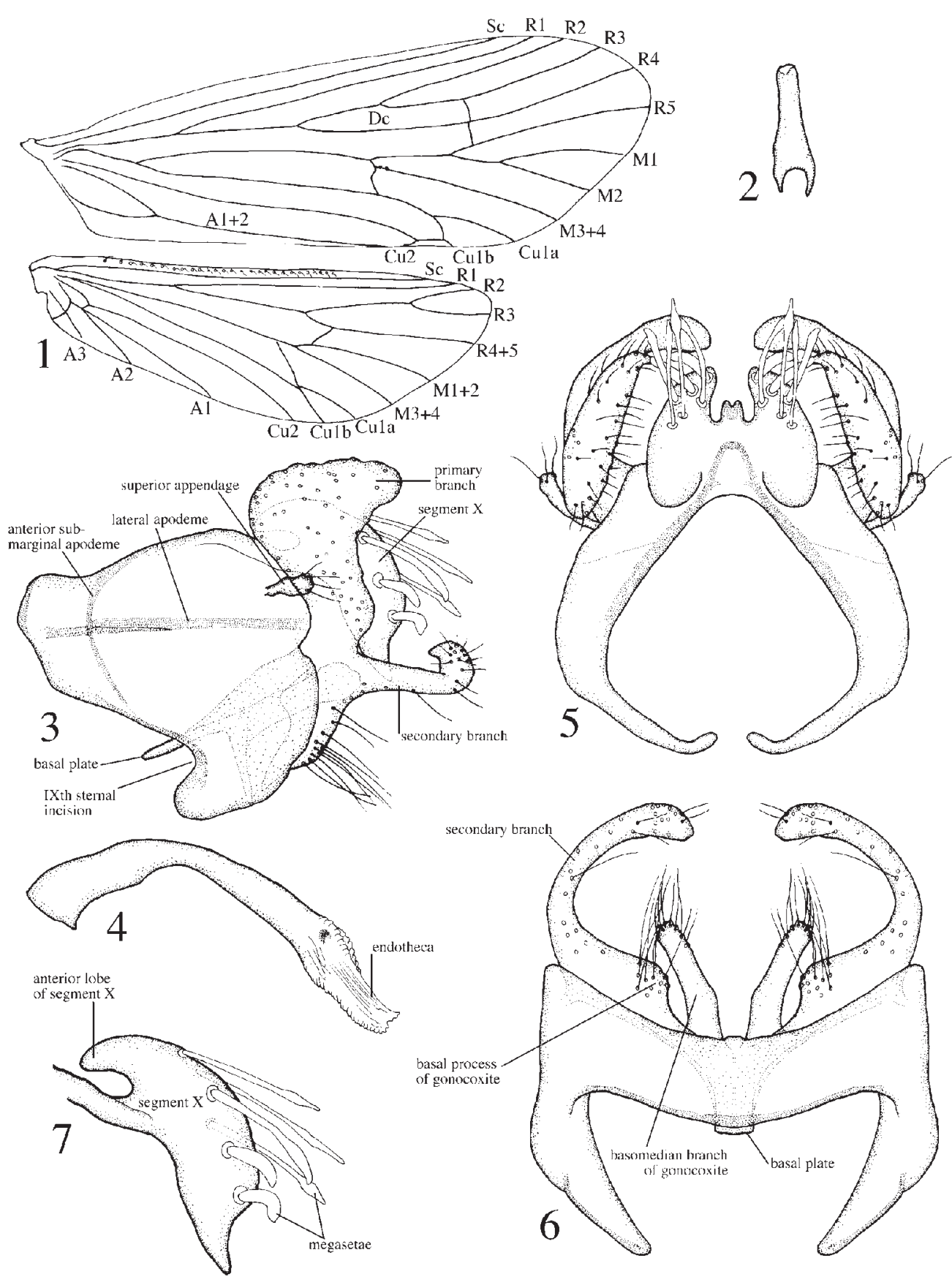

Fig. 1-7. Helicopsyche pellmyri sp. n., male. - 1, right wings; 2, VIth sternal process; 3, genitalia, lateral view; 4, phallus, lateral view; 5, genitalia, dorsal view; 6, genitalia, ventral view; 7, Xth tergum, lateral view. 


\section{Etymology}

H. pellmyri, after O. Pellmyr, one of the collectors of the holotype.

\section{Description}

Male (figs. 1-7). - Head: maxillary palp joints equally long; scape about as long as basal joint of maxillary palp; 51 flagellomeres. Cephalic warts strongly pyriform, extended towards anterior head margin. Interantennal warts absent. Wings (fig. 1): fore wing $6.3 \mathrm{~mm}$; fork 1 originates about midway on Dc; Dc nearly twice $M_{2}$ length; $M_{2}$ about $2 \times$ longer than distal part of $\mathrm{M}_{1+2}$; crossvein $\mathrm{M}-\mathrm{Cu}$ meets $\mathrm{Cu}_{1}$ at some distance before bifurcation of $\mathrm{Cu}_{1}$, this distance is about equal to the length of $\mathrm{Cu}_{1 \mathrm{a}}$; Crossvein $\mathrm{Cu}_{1}$ $\mathrm{Cu}_{2}$ present. Posterior wing $4.7 \mathrm{~mm} ; 27$ hamuli; $\mathrm{R}_{2+3}$ about $1.5 \times$ longer than $\mathrm{R}_{2}$; Crossvein $\mathrm{M}-\mathrm{Cu}$ tangent to point of bifurcation of $\mathrm{Cu}_{1}$; basal brush of long, dark setae, and scaloid setae absent. Fore leg posterior spur length about $0.5 \times$ anterior spur length. Abdomen with VIth sternal process well developed (fig. 12). Genitalia (figs. 3-7): IXth segment produced anterodorsad; submarginal apodeme well developed (fig. 3). IXth sternal incision V-shaped, wide and deep (fig. 3). Superior appendage originates at some distance dorsally to lateral apodeme and directed posteriad. Xth tergum, lateral view, strongly produced dorsally and expanded anteriad, forming an anterior lobe (figs. 3, 5, 7). Xth tergal megasetae present in two groups: an anterior group includes four long, drop-shaped megasetae, and a postero-lateral group includes two knife-shaped megasetae (figs. 5, 7). Xth tergum dorsal margin about parallel with ventral margin in lateral view, tapers strongly towards apex (fig.
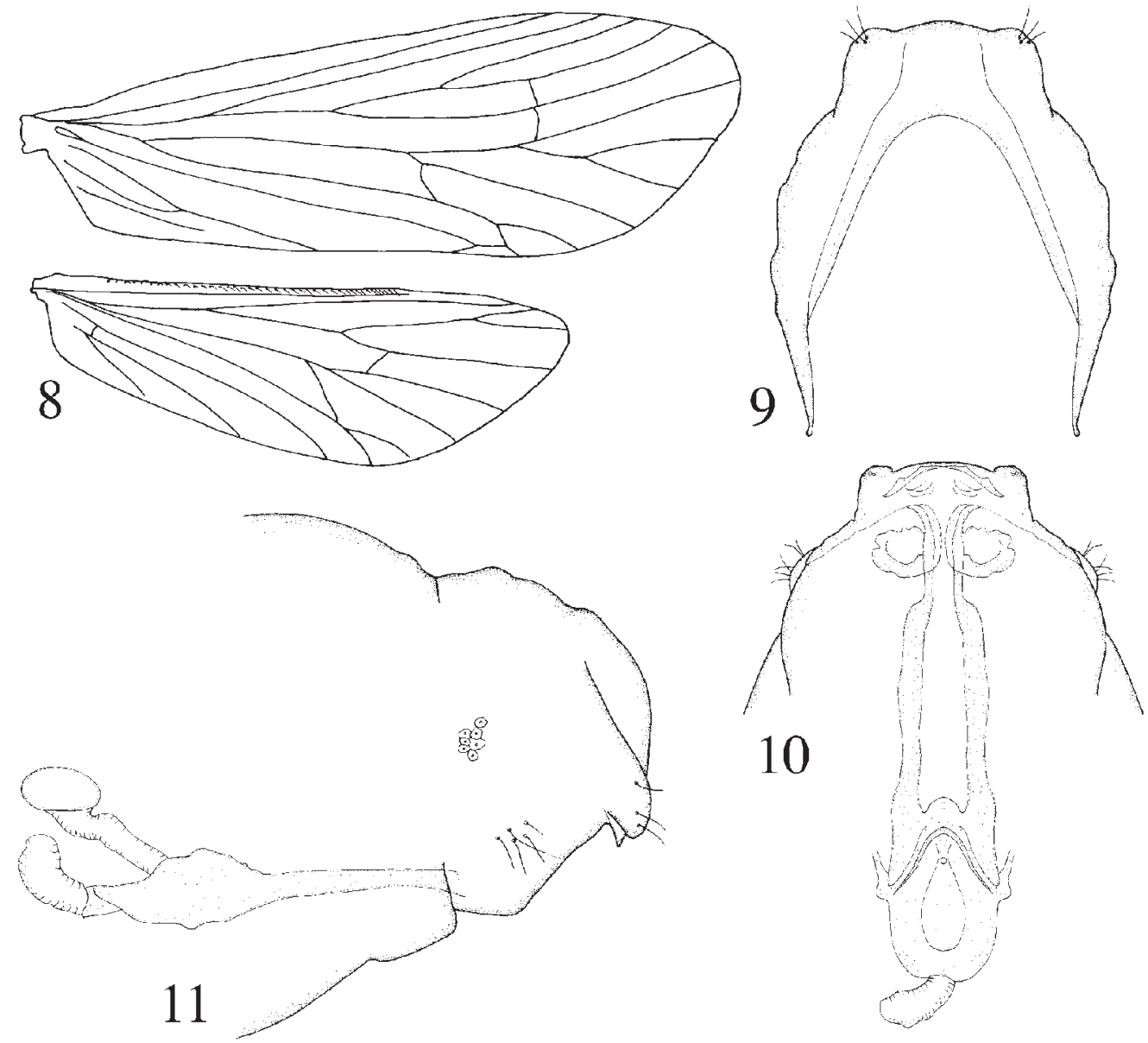

Figs. 8-11. Helicopsyche pellmyri sp. n., female. -8 , right wings; 9, genitalia, dorsal view; 10, genitalia, ventral view; 11, genitalia, lateral view. 
7). Gonocoxal primary branch about $4 \times$ broader than secondary branch (fig. 3); strongly sigmoid, with anterior and dorsal margins acute angled (fig. 3); longer than secondary branch. Secondary branch strongly curved mediad, with apex slightly clubshaped (fig. 6); having broad basal part produced into a rounded process (fig. 6). Basomedian branch, lateral view, slightly club-shaped (fig. 3); in ventral view, parallel sided, slightly angled at basal part (fig. 6). Basal plate anteriorly broad, apex truncate (fig. 6). Phallus (fig. 4) without sclerous processes; lateral view, basally about $2 \times$ as wide as median part; angled ventrad at about $1 / 3$ its length.

Female (figs. 8-11). - Wings (fig. 8): Fore and hind wings as in male, except posterior wing with 40 hamuli and crossvein $\mathrm{M}-\mathrm{Cu}$ meets $\mathrm{Cu}_{1}$ some distance before bifurcation of $\mathrm{Cu}_{1}$. Abdominal VIth sternal process well developed. Genitalia with a lateral setae group located on ventrolateral part of segment IX (figs. 9-11). Lateral comb forms distinct process located medially on segment IX (figs. 10, 11). Segment $\mathrm{X}$ with dorsal branch as long as ventral branch, dorsal branch broad and partly hides the ventral branch in lateral view (fig. 11); dorsal branch slightly produced in dorsal aspect; with few, short apical setae (figs. 9, 11). Vagina (fig. 10) sclerotized along its length, with a pair of lateral, transverse ring-like structures situated close to posterior end of vagina (fig. 10). Vaginal sclerite, ventral view, about parallel sided; anteriorly rounded (fig. 10).

Larva and pupa. - Unknown.

\section{Helicopsyche koghiensis sp. n.}

(figs. 12-18)

\section{Type material}

Holotype, ô (in alcohol), NEW CALEDONIA: Koghi R., Mts de Koghi, 250m, 10.i.1966 (G. F. Edmunds) (ROM).

\section{Diagnosis}

H. koghiensis sp. n. can be distinguished from other Helicopsyche species by the hind wing which has a brush of long, dark anal setae and scaloid setae arranged along $A_{1}$ and $\mathrm{Cu}_{2}$ (fig. 12); the long, thin, ventrally curved and apically pointed Xth tergum (fig. $15)$; and the shape of the gonocoxal primary branch (fig. 15).

\section{Etymology \\ H. koghiensis, named after Koghi Mts.}

\section{Description}

Male. - Head: maxillary palp joints equally long; scape about as long as basal maxillary palp joint; flagella broken. Cephalic warts pyriform, expanded towards anterior head margin. Wings (figs. 12-14): Fore wing $4.0 \mathrm{~mm}$; fork 1 originates distally on Dc; Dc about $1.7 \times$ longer than $\mathrm{M}_{2} ; \mathrm{M}_{2}$ about $1.8 \times$ longer than distal part of $\mathrm{M}_{1+2}$; crossvein $\mathrm{M}-\mathrm{Cu}$ meets $\mathrm{Cu}_{1}$ at some distance basally to bifurcation of $\mathrm{Cu}_{1}$, the distance is about $1.4 \times \mathrm{Cu}_{1 b}$; crossvein $\mathrm{Cu}_{1}-\mathrm{Cu}_{2}$ apparently absent. Hind wing $3.4 \mathrm{~mm} ; 27$ hamuli; crossvein $\mathrm{M}-\mathrm{Cu}$ fuses with fork $5 ; \mathrm{R}_{2}$ length about $0.5 \times \mathrm{R}_{2+3}$ length; anal area with brush of long, dark setae (figs. 12, 14); $\mathrm{Cu}_{2}$ and $\mathrm{A}_{1}$ covered by scaloid setae (figs 12,13). Fore leg posterior spur length about $0.5 \times$ anterior spur length. Abdomen: VIth sternal process well developed. Genitalia (figs. 15-18): segment IX without anterior submarginal apodeme; anteriorly rounded, slightly detached anteriorly to transverse tergal apodeme (fig. 15); sternal incision absent (fig. 15). Superior appendage slender, slightly club shaped (figs. 15-17). Xth tergum deeply cleaved (fig. 17); curves smoothly ventrad and tapers apically (fig. 15); without megasetae; with two pairs of basal setae, four pairs of apical setae (figs. 15, 17). Gonocoxite with primary and secondary branches about equally long (fig. 15); primary branch basally bent posterodorsad, with rounded apex in lateral view (fig. 15); in dorsal view (fig. 17) overlaying Xth tergum, pointed; secondary branch tapers and curves ventrad (fig. 15), medially substraight but apically slightly curved mediad (fig. 18); basally produced into broad process (fig. 18); basomedian branch short, club shaped, slightly curved mediad (figs. 15, 18). Basal plate (figs. 15,18 ) short, thin and anteriorly rounded. Phallus (fig. 16) without sclerous processes; basally substraight; medially strongly bent ventrad.

$$
\text { Female, larva, pupa. - Unknown. }
$$

\section{Helicopsyche arma sp. n.}

(figs. 19-23, 94)

\section{Type material}

Holotype, ô (pinned), NEW CALEDONIA: Mt. Dzumac, $820 \mathrm{~m}, 166^{\circ} 26^{\prime} 40^{\prime \prime} \mathrm{E}, 22^{\circ} 3^{\prime} \mathrm{S}, 25 . x .1986$, UV trap (R. Brown \& O. Pellmyr) (NMNH).

\section{Diagnosis}

H. arma sp. n. can be distinguished from other $\mathrm{He}$ licopsyche species by the highly sclerotized lateral Xth tergal processes (figs. 19, 20); the sickle shaped primary gonocoxal branch (fig. 19); the strongly produced basal process (figs. 19, 21); the short, apically undulated basomedian gonocoxal branches; and the spine shaped apical sclerous phallic processes (fig. 23). 


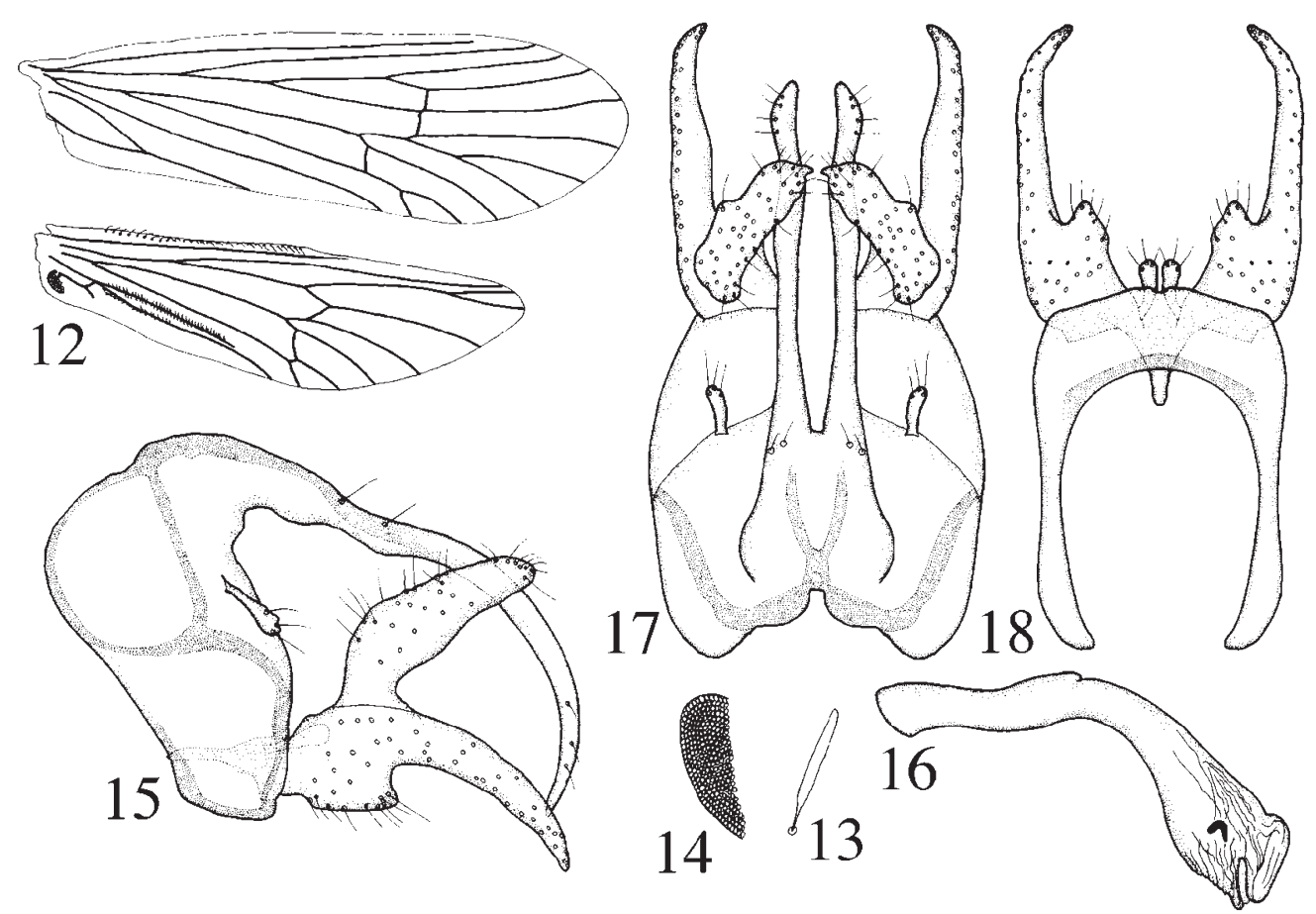

Figs. 12-18. Helicopsyche koghiensis sp. n., male. - 12, right wings; 13, scaloid seta from cubital veins, highly magnified; 14, group of setae bases in anal region, highly magnified; 15, genitalia, lateral view; 16, phallus, lateral view; 17, genitalia, dorsal view; 18 , genitalia, ventral view.

\section{Etymology}

H. arma, from Latin, arms, weapons, tools, refers to the strongly sclerotized, additional processes on the Xth tergum.

\section{Description}

Male. - Wings (fig. 94). Fore wing base color is dark brownish, without particular metallic reflections; with a broad silver-blue band in R-section and a small silver-blue spot in distal A-region. In sunlight the spots appear silver blue, metallic red or white, depending on light angle. Posterior wings anal area, below the long setae brush, is covered by microtrichia which gives a deep blue color in sunlight. The anal brush appears pale brownish in sunlight. Genitalia (figs. 19-23): IXth segment subtrianguloid in lateral view (fig. 19); submarginal apodeme absent; sternal incision small; anterior sternal margin substraight (fig. 19). Superior appendage originates from posterior margin of Xth segment (fig. 19); club shaped. Xth tergum, lateral view (fig. 19), basally enlarged into a dorsal process; distal half slender, substraight, and with dorsal and ventral margins about parallel; without megasetae; apex deeply incised. Xth tergum with three pairs of strongly sclerotized processes as in figs. 19 and 20. Gonocoxite with cicle shaped, dilated primary branch; secondary branch substraight, apically slightly curved dorsad (fig. 19). Basal process of gonocoxite strongly produced posteriad, tube shaped (figs. 19, 21). Basomedian branch apparently completely fused with basal part of gonocoxite (fig. 21); apex with erected, bulbous setae bases. Basal plate short, pointed (fig. 21). Phallus with a pair of dorsal, apically pointed sclerous processes (fig. 23); gently curved ventrad (fig. 22); basally slender and dilates smoothly posteriorly (fig. 23).

Female, larva and pupa. - Unknown.

Helicopsyche rossi sp. n.

(figs. 24-30)

\section{Type material}

Holotype, $\hat{0}$ (in alcohol), NEW CALEDONIA: La Crouen, 31.i.1963, light trap (C. Yoshimoto \& N. Krauss) (ROM). 

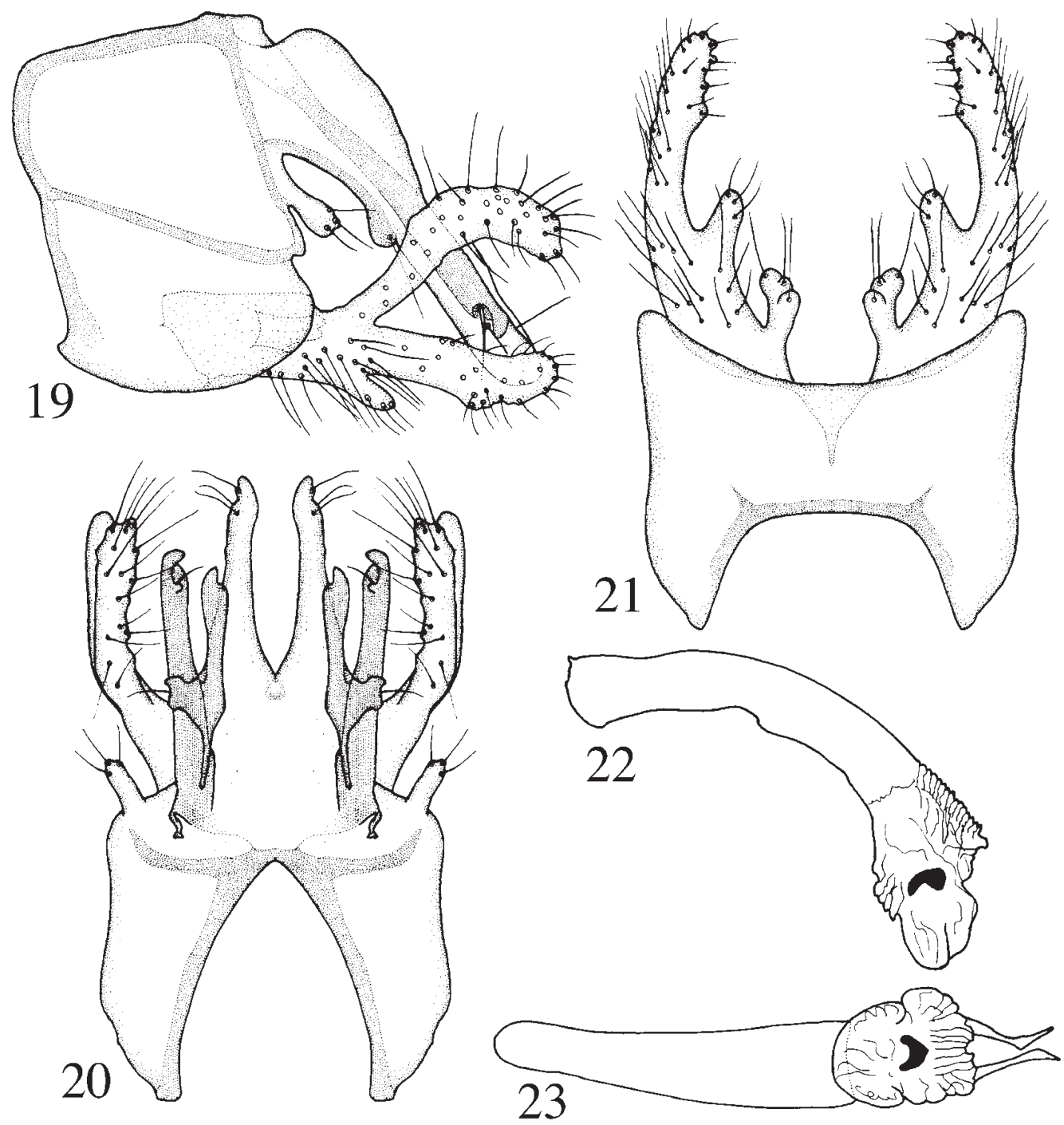

Figs. 19-23. Helicopsyche arma sp. n., male. - 19, genitalia, lateral view; 20, genitalia, dorsal view; 21, genitalia, ventral view; 22, phallus, lateral view; 23 , phallus, ventral view.

\section{Diagnosis}

H. rossi sp. n. can be distinguished from other $\mathrm{He}$ licopsyche species by the Xth tergum which is densely covered by long, drop shaped megasetae (figs. 28, 30 ); the broad gonocoxal basomedian branches (fig. 29); and the strongly ventrad curved phallus (fig. 26).

\section{Etymology}

H. rossi, named after H. H. Ross.

\section{Description}

Male. - Head unknown. Fore wing (fig. 24) 7.2 $\mathrm{mm}$; fork 1 originates medially on Dc; Dc about $1.6 \times$ longer than $M_{2} ; M_{2}$ nearly $2 \times$ longer than distal part of $M_{1+2}$. Hind wing unknown. Genitalia (figs. 25-30): IXth segment, lateral view (fig. 25) slightly produced anteriad; submarginal apodeme well developed; sternal incision deep and wide; dorsal margin strongly convex. IXth segment, dorsal view (fig. 27), with sigmoid median margins. Superior appendage long, slender, club shaped, originates at some distance from lateral apodeme (figs. 25, 28). Xth tergum, lateral view (figs. 25, 30), strongly produced dorsad and with a small anterior lobe; 
about nine drop shaped megasetae in basal group, and a knife shaped megaseta medially (figs. 28, 30); apically gently tapering, with group of about eight dorsal setae (fig. 30). Gonocoxite, lateral view (fig. 25), with broad, sigmoid primary branch and slender, tuboid secondary branch. In ventral view (fig. 29) secondary branches gently curved basad; basal branch of gonocoxite slightly edged. Basomedian branches well developed; subparallel in lateral and ventral views (figs. 25, 29), slightly curved laterad (fig. 29). Basal plate long, anteriorly slightly truncated (fig. 29). Phallus without sclerous proces-

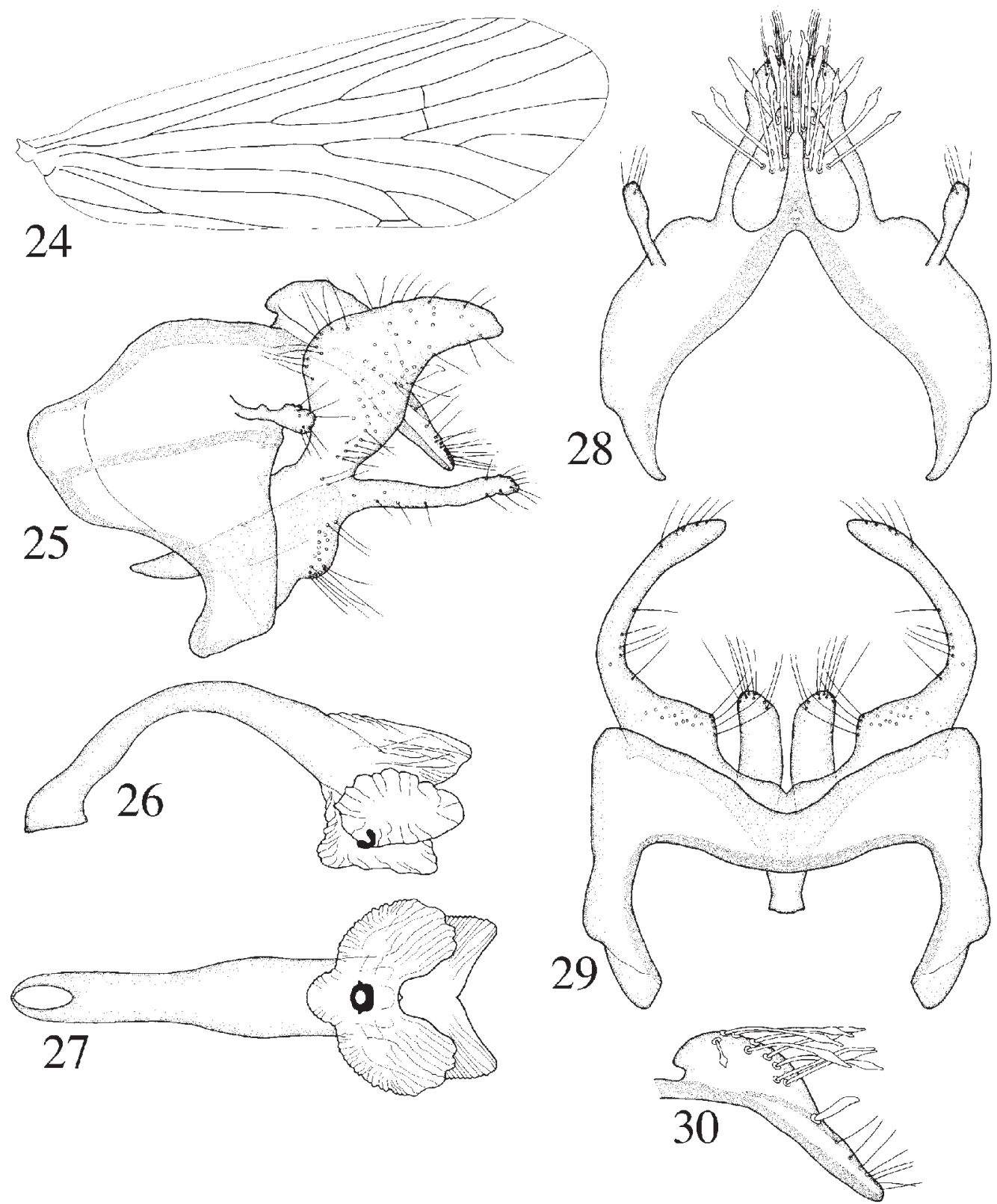

Figs. 24-30. Helicopsyche rossi sp. n., male. - 24, Right fore wing; 25, genitalia, lateral view; 26, phallus, lateral view; 27, phallus, ventral view; 28, genitalia, dorsal view; 29, genitalia, ventral view; 30, Xth tergum, lateral view. 


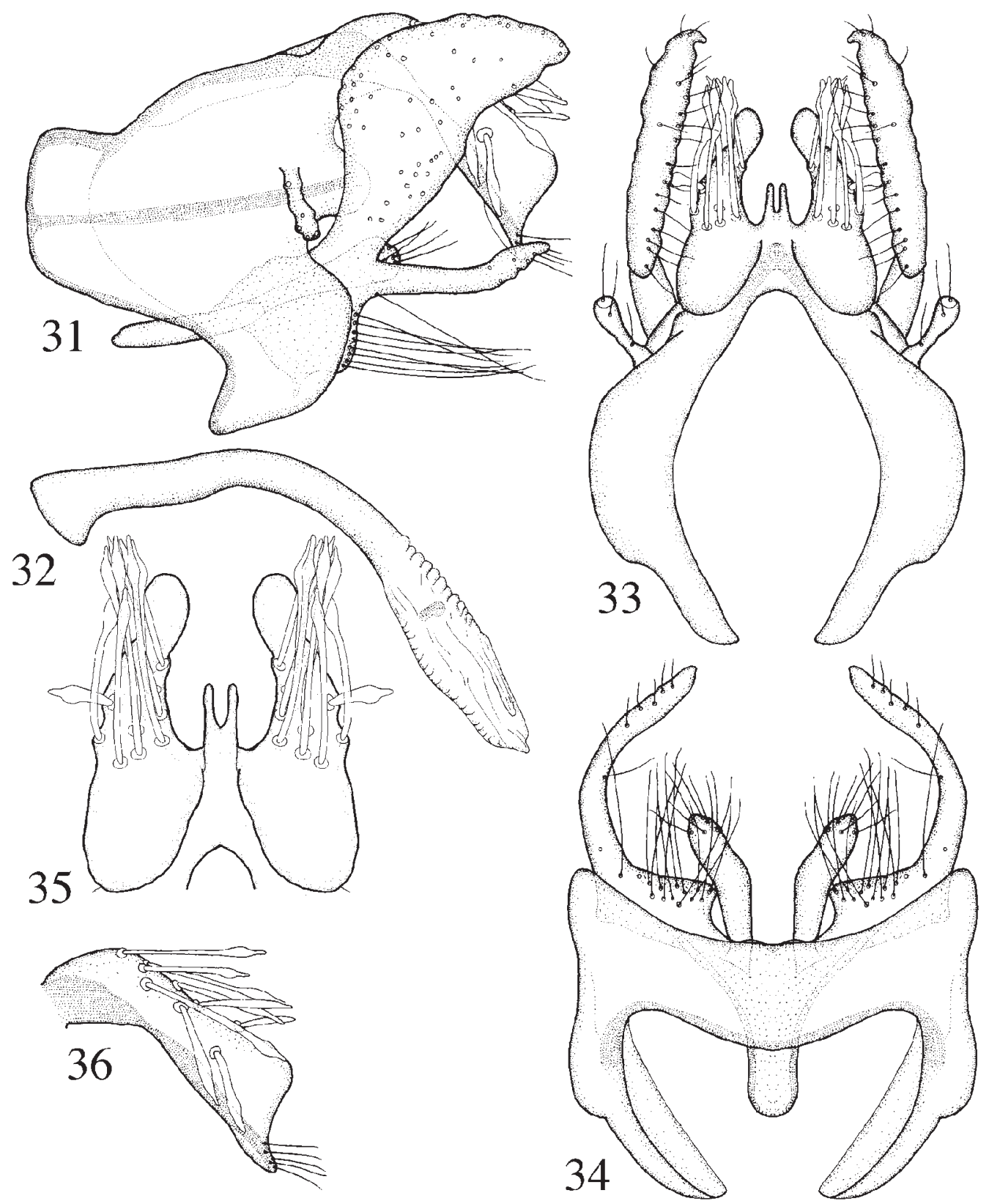

Figs. 31-36. Helicopsyche neocaledonia sp. n., male. - 31, genitalia, lateral view; 32, phallus, lateral view; 33, genitalia, dorsal view; 34, genitalia, ventral view; 35, Xth tergum, dorsal view; 36, Xth tergum, lateral view. 
ses; strongly curved ventrad (fig. 26); posterior half about $2 \times$ broader than basal half (fig. 27).

Female, larva and pupa. - Unknown.

\section{Helicopsyche neocaledonia sp. n.}

(figs. 31-36)

\section{Type material}

Holotype, $\widehat{o}$ (in alcohol), NEW CALEDONIA: tributary Nehoue River, Koumac-Bonde-Ouegoua Road, 18.ix.1965 (F. Starmuhlner) (111/2) (ROM).

Paratypes, 2 o pupae (in alcohol), as holotype, (ROM).

\section{Diagnosis}

H. neocaledonia sp. n. can be distinguished from other Helicopsyche species by the IXth segment which is anteriorly produced into a rectanguloid process (fig. 31); the basomedian branches of gonocoxite that are slightly laterad angled (fig. 34); and by the presence of two groups of about eight drop shaped and one thick Xth tergal megasetae (figs. 35, 36).

\section{Etymology}

\section{H. neocaledonia, after NEW CALEDONIA.}

\section{Description}

Male. - Head and wings unknown. Genitalia (figs. 31-36): IXth segment, lateral view (fig. 31), produced anterodorsad into a rectangle; dorsal margin slightly convex; with well developed submarginal apodeme; sternal incision deep and broad. IXth median tergal margins ovoid in dorsal view (fig. 33). Superior appendage tuboid, originates at some distance dorsally to lateral apodeme (fig. 31). Xth tergum, lateral view (fig. 36), strongly produces dorsad and tapers strongly towards apex; with basal group of about eight drop shaped megasetae and a single lateromedian, drop shaped megaseta (figs. 31, 35, 36); apical incision with two small, median lobes (fig. 35). Gonocoxite, lateral view (fig. 31), with broad primary branch having strongly convex anterior margin and substraight posterior margin; secondary branch tuboid (figs. 31, 34 ), curved mediad, basal process pointed. Basomedian branches angled laterad in ventral view (fig. 34), and club shaped in lateral view (fig. 31). Basal plate long, broad and anteriorly rounded (figs. 31, 34). Phallus (fig. 32) as in $H$. rossi sp. n.

Female and larva. - Unknown.
Helicopsyche browni sp. n. (figs. 37-43)

\section{Type material}

Holotype, $\widehat{\delta}$ (in alcohol), NEW CALEDONIA: Riviere Bleue, 16640'20'”, 226'S, 8.xi.1986, UV trap (R. Brown \& O. Pellmyr) (NMNH).

Paratypes, $2 \widehat{0}$ (in alcohol), NEW CALEDONIA: stream on Mt. Pouédihi, $15 \mathrm{~km}$ W of Ouénarou Forest Station, on Eaux et Forêts Road, 153 m., N50, 5.xi.1972 (W. L. \& J. G. Peters) (ROM).

\section{Diagnosis}

H. browni sp. n. males can be distinguished from other Helicopsyche species by the rounded, and broad anteriorly produced process of segment IX (fig. 39); the substraight, slightly sigmoid posterior margin of the gonocoxal primary branch; the rounded anterodorsal margin (fig. 39); the acute angled primary and secondary branches (fig. 39); and the about twelve drop shaped Xth tergal megasetae (figs. 40, 42).

\section{Etymology}

H. browni, named after one of the collectors, R. Brown.

\section{Description}

Male. - Head maxillary palp joints equally long. Scape as long as basal joint of maxillary palp; with 54 flagellomeres. Cephalic warts pyriform, strongly extended towards anterior head margin. Wings (fig. 37): fore wing $6.0 \mathrm{~mm}$; fork 1 originates about midway on Dc; Dc about $2.5 \times$ longer than $\mathrm{M}_{2} ; \mathrm{M}_{2}$ $1.6 \times$ longer than distal part of $\mathrm{M}_{2+3} ; \mathrm{Cu}_{1 \mathrm{a}}$ basally faded; crossvein $\mathrm{Cu}_{1}-\mathrm{Cu}_{2}$ apparently absent. Hind wing $4.3 \mathrm{~mm}$; with 27 hamuli; $\mathrm{R}_{2}$ slightly shorter than $\mathrm{R}_{2+3}$; crossvein $\mathrm{M}-\mathrm{Cu}$ meets $\mathrm{Cu}$ at some distance basally to fork 5; brush of long, black setae and scaloid setae absent. Fore leg posterior spur about $0.5 \times$ anterior spur length. Abdomen with well developed VIth sternal process (fig. 38). Genitalia (figs. 39-43): IXth segment produced anteriorly into a rounded process (fig. 39); submarginal apodeme present (fig. 39); IXth sternal incision wide and deep (fig. 39). Superior appendage directed posteroventrad, originates near dorsal margin of lateral apodeme. Xth tergum, lateral view (figs. 39, 42), strongly produced dorsad and expands into anterior lobe (fig. 42). Xth tergal megasetae arranged into a median group with three drop shaped megasetae (fig. 40), and a lateral group including two drop and tube shaped megasetae and a distal thick, drop shaped megaseta (figs. 40, 42). Distal part of Xth tergum generally wide, tapers strongly near apex (fig. 42). Gonocoxite, lateral view (fig. 39), with primary branch more than $3 \times$ broader, and 


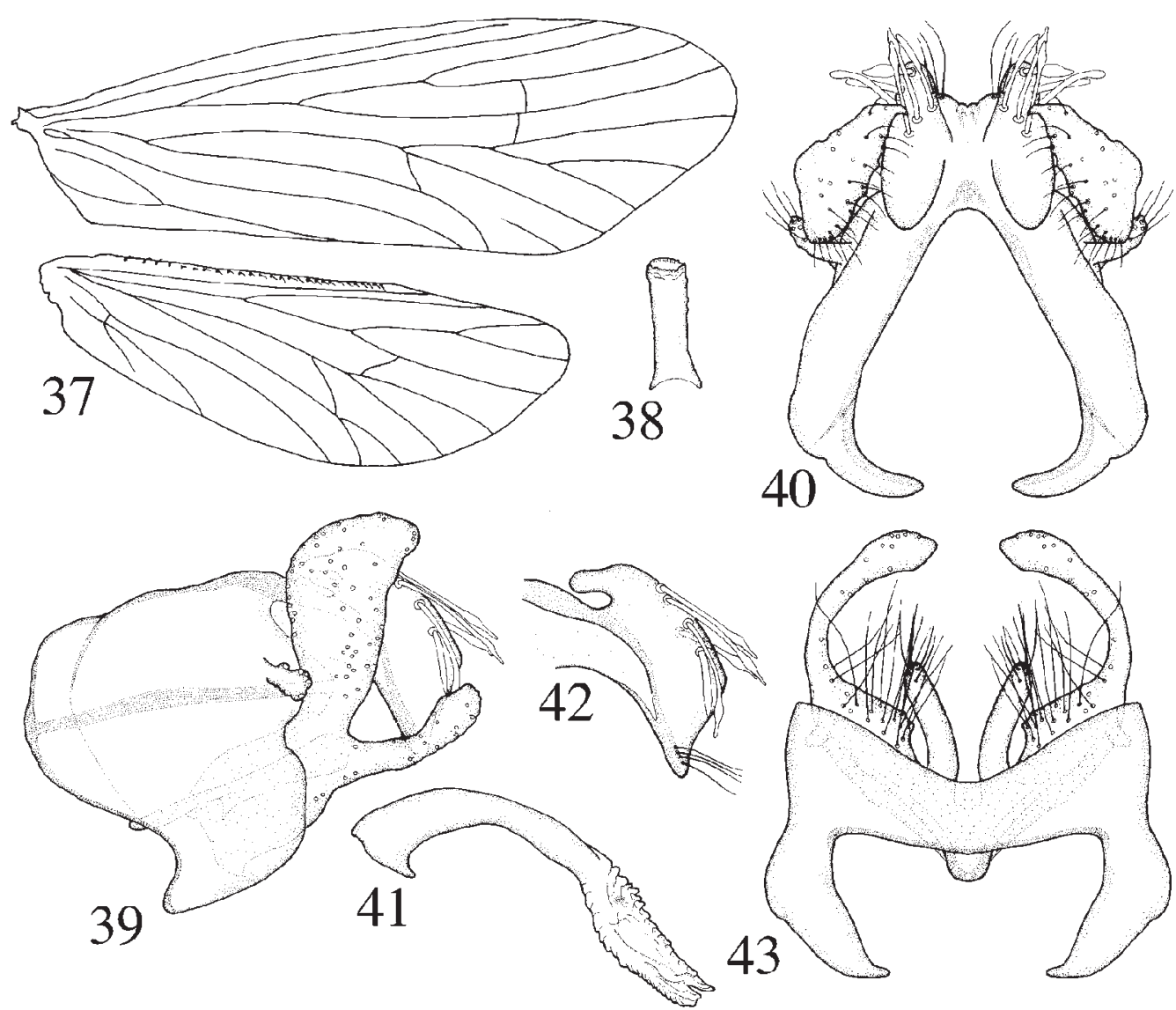

Figs. 37-43. Helicopsyche browni sp. n., male. - 37, right wings; 38, VIth sternal process, ventral view; 39, genitalia, lateral view; 40, genitalia, dorsal view; 41, phallus, lateral view; 42, Xth tergum, lateral view; 43, genitalia, ventral view.

slightly longer than secondary branch; slightly sigmoid. Secondary branch, ventral view (fig. 43), slender, strongly curved mediad and with slightly club shaped apex; basal part wide and produced into a small, pointed process. Basomedian branch of gonocoxite slightly broader towards apex in lateral view (fig. 39), but parallel shaped and curved laterad in ventral view (fig. 43). Basal plate (fig. 43) anteriorly broad, with rounded apex. Phallus (fig. 41) without sclerous processes; curved ventrad along its length.

Female, larva, pupa. - Unknown.

\section{Helicopsyche baroua sp. $\mathrm{n}$.} (figs. 44-50)

\section{Type material}

Holotype, ơ (in alcohol), NEW CALEDONIA: Mt.
Stream up Boulari River, 3.ix.1958, light trap (C. R. Joyce) (вMH).

Paratype, ô pupa (in alcohol), NEW CALEDONIA: Baroua River, between Bouail and Poyabei bridge Terr. Rte. 1, 1.viii.1965 (F. Starmuhlner) (ROM).

\section{Diagnosis}

$H$. baroua sp. n. can be distinguished from other Helicopsyche species by the dorsally pointed IXth segment (fig. 45); rounded expansion of the Xth segment (figs. 45, 46, 49); long lateral processes which originates basolaterally on the Xth tergum (figs. 46, 49); the sickle shaped gonocoxal primary branch (fig. 45); the pair of dorsad, hook shaped apical; and the ventrad hook shaped subapical sclerous phallic processes (fig. 48). 


\section{Etymology}

H. baroua, from Baroua River, the type locality.

\section{Description}

Male. - Head: maxillary palp joints equally long; scape slightly longer than joints of maxillary palp; flagella broken; cephalic warts pyriform. Wings (fig. 44): fore wing $3.8 \mathrm{~mm}$; fork 1 originates about medially on dc; Dc nearly $2 \times$ longer than $\mathrm{M}_{2} ; \mathrm{M}_{2}$ about $1.5 \times$ longer than $\mathrm{M}_{1+2} ; \mathrm{Cu}_{1 \mathrm{a}}$ and $\mathrm{Cu}_{1 \mathrm{~b}}$ present;
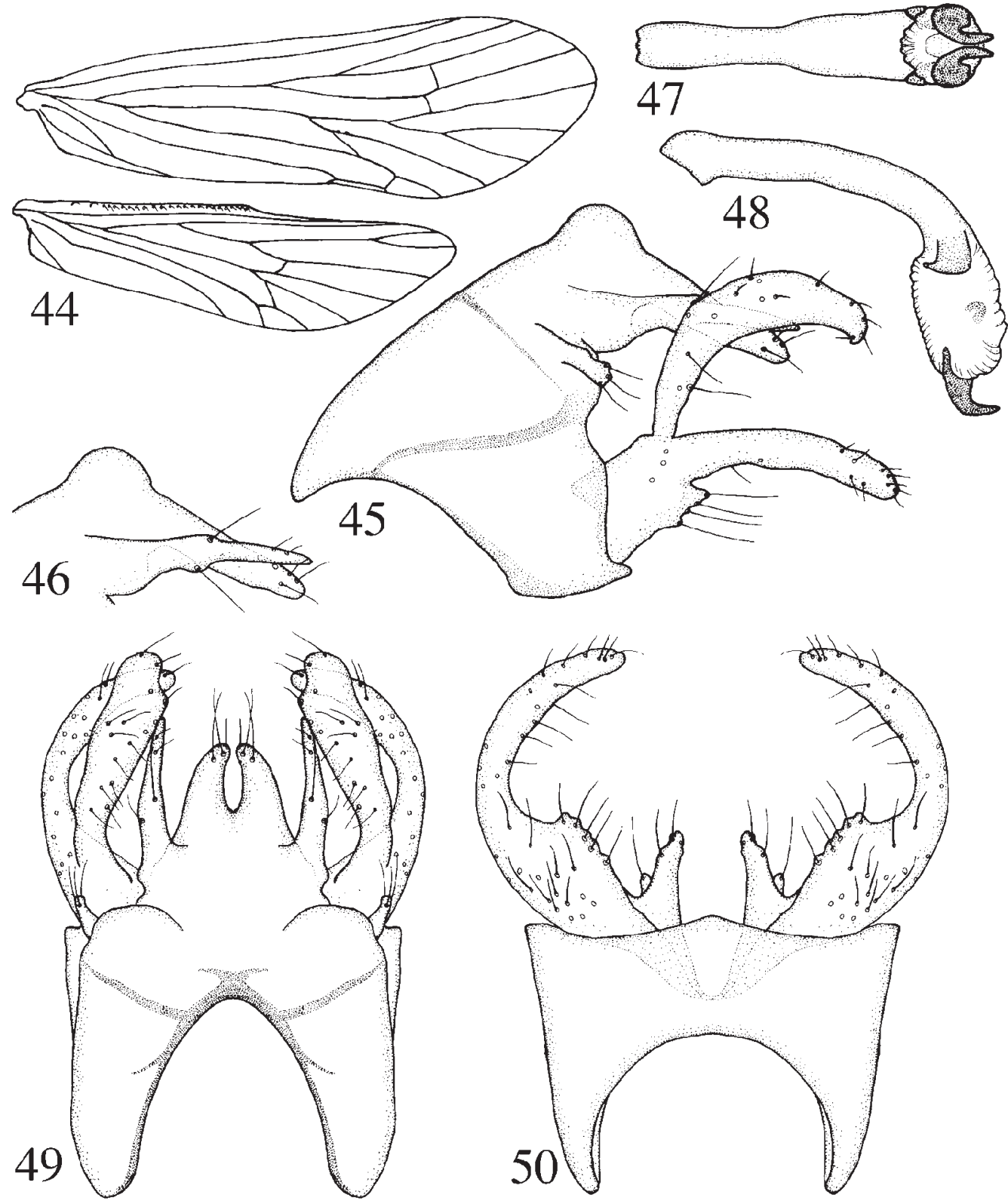

Figs. 44-50. Helicopsyche baroua sp. n., male. - 44, genitalia, lateral view; 46, Xth tergum, lateral view; 47, phallus, ventral view; 48, phallus, lateral view; 49, genitalia, dorsal view; 50, genitalia, ventral view. 


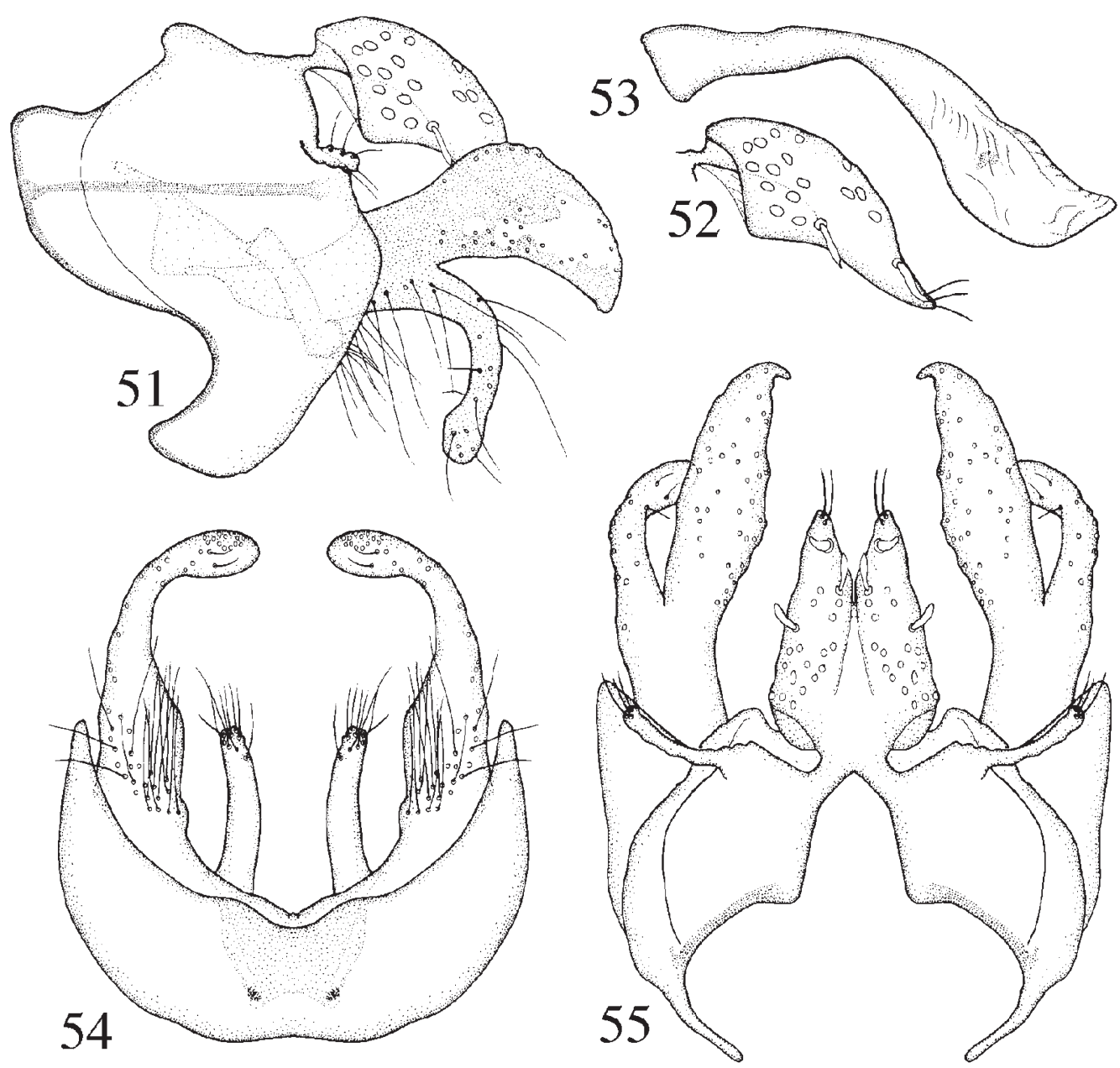

Figs. 51-55. Helicopsyche ouaroua sp. n., male. - 51, genitalia, lateral view; 52, Xth tergum, lateral view; 53, phallus, lateral view; 54, genitalia, ventral view; 55, genitalia, dorsal view.

crossvein $\mathrm{Cu}_{1}-\mathrm{Cu}_{2}$ present. Hind wing $2.9 \mathrm{~mm}$; with 24 hamuli; $\mathrm{R}_{2+3}$ about $2 \times$ longer than $\mathrm{R}_{2}$; crossvein $\mathrm{M}-\mathrm{Cu}$ meets $\mathrm{Cu}$ well into $\mathrm{Cu}_{1 \mathrm{a}}$; anal setae brush and scaloid setae absent. Fore leg posterior spur length about ${ }^{1}{ }_{3} \times$ anterior spur length. Genitalia (figs. 4550): IXth segment strongly produced and tapers anteriad, slightly curved ventrad (fig. 45); dorsal margin substraight (fig. 45); anteroventral margin concave (fig. 45); submarginal apodeme absent. Sternal incision absent. Superior appendage tuboid, oriented posteroventrad (fig. 45); originates at some distance dorsal to lateral apodeme. Xth tergum, lateral view (figs. 45, 46) with dorsobasal, rounded process; distal half tapers slightly towards apex; megasetae absent; setae present on apex. In dorsal view (fig. 49), basally broad but tapers slightly towards apex; the two apical lobes converge. A second pair of processes originate from basal part are oriented posteriad, substraight, and with dorsal and lateral setae (figs. 46, 49). Gonocoxite, lateral view (fig. 45) with broad base; diverges into two equally long and thick primary and secondary branches; primary branch sickle shaped; sec-

Figs. 56-61. Helicopsyche fusca sp. n., male. - 56, right wings; 57, genitalia, lateral view; 58, phallus, lateral view; 59, phallus, dorsal view; 60, genitalia, dorsal view; 61, genitalia, ventral view. 

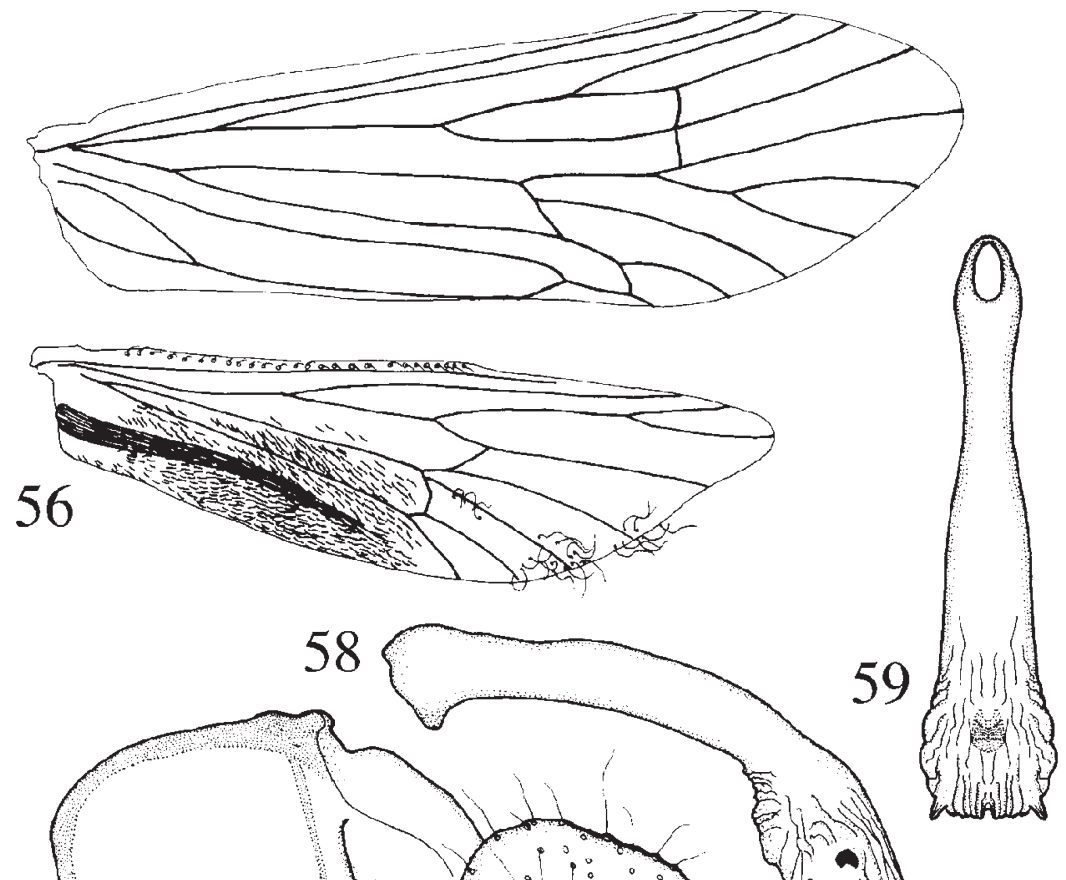

57
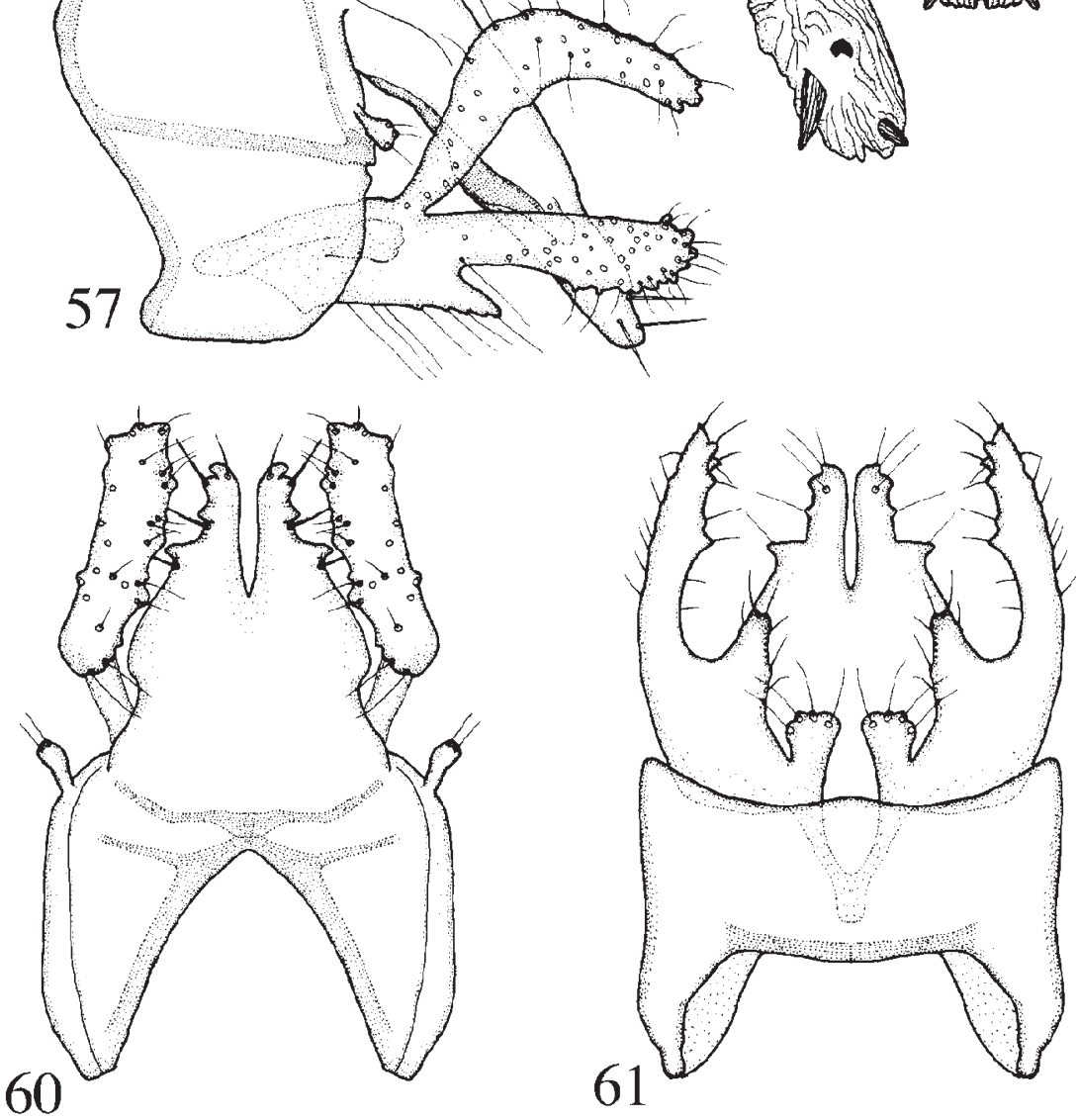
ondary branch slightly curved ventrad; in ventral view (fig. 50) with strongly mediad curved secondary branches; basal part wide and produced into short processes with undulated median margins. Basomedian branch trianguloid (fig. 50); with strongly erected seta base on middle part (fig. 50). Basal plate short, rounded (fig. 50). Phallus with two pairs of sclerous processes: a pair of short, broad downwardly hooked subapical process (fig. 47), and a pair of slightly longer, upwardly hooked apical process (figs. 47, 48); in ventral view (fig. 47), with distal part slightly broader than basal half.

Female and larva. - Unknown.

\section{Helicopsyche ouaroua sp. n. (figs. 51-55)}

\section{Type material}

Holotype, ô pupa (in alcohol), NEW CALEDONIA: Ouarou River source of Tchamba River, $\mathrm{N}$ of Ponérihouen, 25.viii.1965 (F. Starmuhlner) (79/2) (EOM). Paratype, ơ (in alcohol), NEW CALEDONIA: Mt. Panié, 30m, near stream at base, 30.x.1986, UV trap (R. Brown \& O. Pellmyr) (NMNH).

\section{Diagnosis}

H. ouaroua sp. n. is distinguished from other Helicopsyche species by the slightly tapering anterodorsal process of the IXth segment (fig.51); the dorsomedian process of the IXth tergite (figs. 51, 55); the ventrally expanded Xth tergum (figs. 51, 52); and the short Xth tergal megasetae (figs. 51, 52, 55).

\section{Etymology}

H. ouaroua, after Ouarou River, the type locality.

\section{Description}

Male. - Head and wings unknown. Genitalia (figs. 51-55): IXth segment strongly produced anteriad into a rectangle (fig. 51); submarginal apodeme present (fig. 51); dorsal margin (fig. 51) projected dorsally into a rounded lobe, also seen in dorsal view (fig. 55); sternal incision deep and wide (fig. 51). Superior appendage originates from posterior margin (figs. 51, 55); oriented laterally (fig. 55) and tuboid. Xth tergum basally incised, widens strongly into a dorsal and a ventral projection (figs. 51, 52); tapers gently towards apex; few apical setae; about 21 pairs of very short megasetae present on lateral faces (figs. 51, 52, 55). Gonocoxite with sicle shaped primary branch about $4 \times$ broader than secondary branch (fig. 51 ); secondary branch curved ventrad (fig. 51); in ventral view with broad base without prominent median process (fig. 54). Basomedian processes tuboid, tapers slightly toward apex, and divergent (fig. 54); club shaped in lateral view (fig. 51). Basal plate long, apparently with bifurcated anterior apex (fig. 54). Phallus (fig. 53) medially bent ventrad.

Female, larva and pupa. - Unknown.

\section{Helicopsyche fusca sp. n.}

(figs. 56-61)

\section{Type material}

Holotype, ô (in Canada balsam), NEW CALEDONIA: Mt. Koghi, 400m, 12-14.xi.1986, UV trap (R. Brown \& O. Pellmyr) (NMNH).

Paratypes, $4 \hat{0}$ (in alcohol), as holotype.

\section{Diagnosis}

H. fusca sp. n. can be distinguished from other $\mathrm{He}$ licopsyche species by the hind wing having a brush of long, dark setae in anal area, scaloid setae in anal area, cubital area and basal half median area, and long, curled setae in distal median and cubital area (fig. 56); the laterally expanded Xth tergum (fig. 60), the trianguloid basal process and the short, club shaped basomedian processes (fig. 61); and phallus with a very short, pointed apical, and longer, pointed subapical sclerous processes (fig. 58).

\section{Etymology}

$H$. fusca, from Latin, fuscus, dark, refers to the darkly pigmented body and wings of the species.

\section{Description}

Male. - Head: maxillary palp with basal joint longer than distal joint. Scape slightly longer than joint of basal maxillary palp; flagella broken. Cephalic warts strongly pyriform, nearly reach anterior head margin. Fore leg posterior spur about $0.5 \times$ anterior spur length. Wings (fig. 56): Fore wing $4.3 \mathrm{~mm}$; fork 1 originates medially on Dc; Dc nearly $2 \times$ longer than $\mathrm{M}_{2} ; \mathrm{M}_{2}$ about $1.6 \times$ longer than distal part of $\mathrm{M}_{1+2}$; crossvein $\mathrm{M}-\mathrm{Cu}_{1}$ meets $\mathrm{Cu}_{1}$ at some distance before bifurcation into fork 5 , the distance is slightly longer than $\mathrm{Cu}_{1 \mathrm{~b}}$ length; crossvein $\mathrm{Cu}_{1}-\mathrm{Cu}_{2}$ present. Hind wing $3.4 \mathrm{~mm} ; 26$ hamuli; crossvein $\mathrm{M}-\mathrm{Cu}$ meets $\mathrm{Cu}_{1}$ on fork 5; $\mathrm{R}_{2}$ about half as long as $\mathrm{R}_{2+3}$. Brush of long, dark setae originates basally in anal area. Scaloid setae are present on a large area covering anal and basal 4/5 cubital area. Long curled setae are present on the distal part of M-area. Genitalia (figs. 57-61): IXth segment anteriorly rounded (fig. 57); submarginal apodeme absent; sternal incision wide, not deep (fig. 57). Superior appendage originates dorsally to lateral apodeme, short, directed posteriad (figs. 57, 60). Xth tergum basally broad, tapers slightly towards apex; without megasetae; expands laterally 

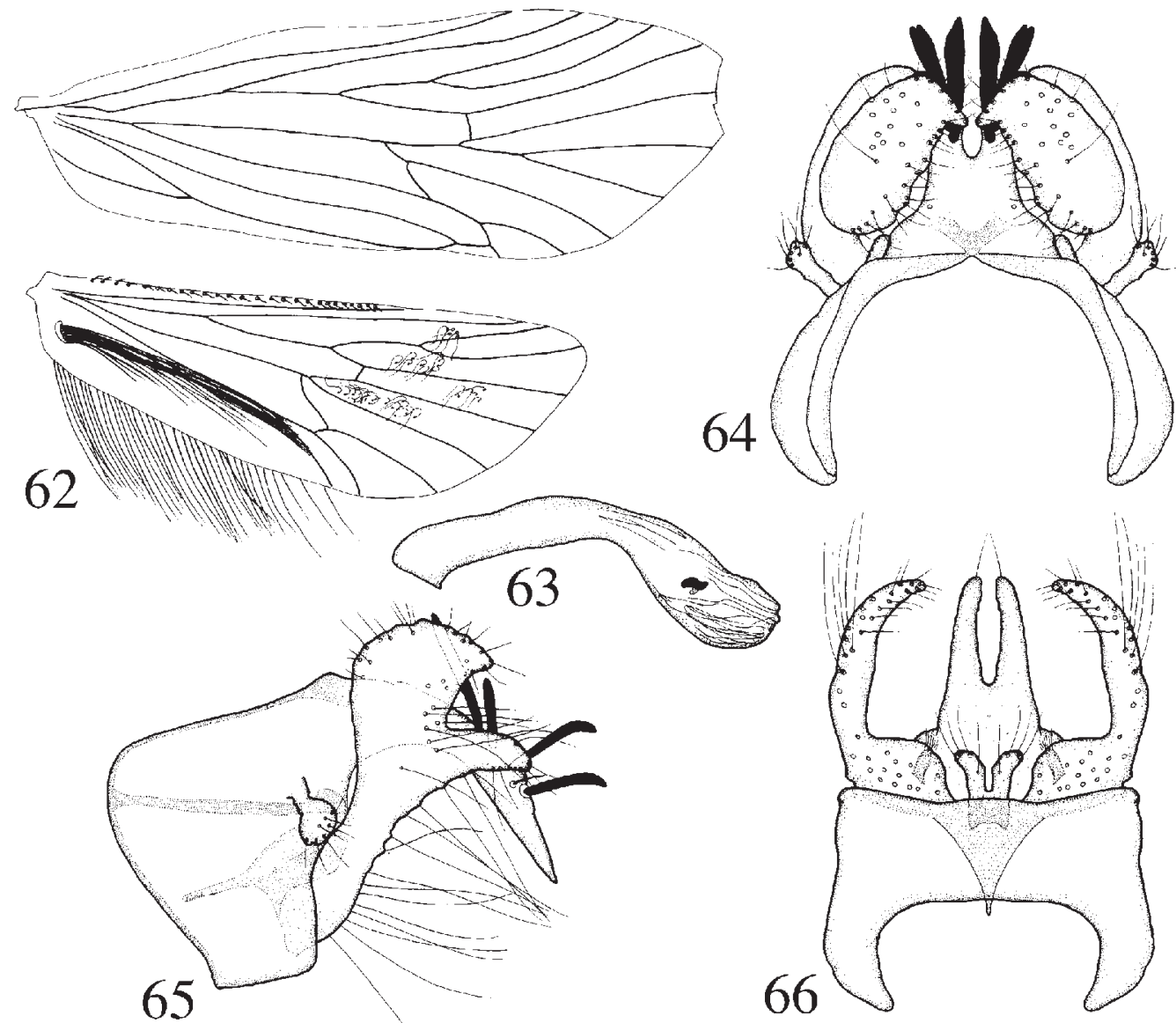

Figs. 62-66. Helicopsyche penicilla sp. n., male. - 62, right wings; 63, phallus, lateral view; 64, genitalia, dorsal view; 65, genitalia, lateral view; 66, genitalia, ventral view.

into basally rounded and distally pointed, sclerotized ridges (figs. 57, 60, 61). Gonocoxal primary branch slender, sicle shaped. Secondary branch substraight and distally dilated (fig. 57); basally broad and expanded into a posteriad process (figs. 57, 61). Basomedian branches short, club shaped. Basal plate short, slender, anteriorly rounded (fig. 61). Phallus substraight; distally slightly bent ventrad (fig. 58); basally slender and swells towards apex (fig. 59); endotheca with two pairs processes (fig. 58).

Female and larva. - Unknown.

\section{Helicopsyche penicilla sp. n.}

(figs. 62-66)

\section{Type material}

Holotype, ô (in alcohol), NEW CALEDONIA: Mé

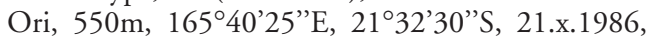
UV trap, (R. Brown \& O. Pellmyr) (NMNH).

\section{Diagnosis}

H. penicilla sp. n. can be distinguished from other Helicopsyche species by having hind wing with a brush of long, dark, anal setae, and a group of long, curled setae in the radial and median area (fig. 62); the Xth tergum which includes four pairs of very long, dark tuboid setae originating from the mid part of the segment (figs. 65, 64); the short gonocoxal basomedian branches which are basally fused into a common plate (fig. 66); and the short, posteriorly oriented processes on the dorsal part, basally on the gonocoxite (fig. 66).

\section{Etymology}

H. penicilla, from Latin, penicillus, brush, refers to the modified wing setae.

\section{Description}

Male. - Head: maxillary palp joints equally long. 

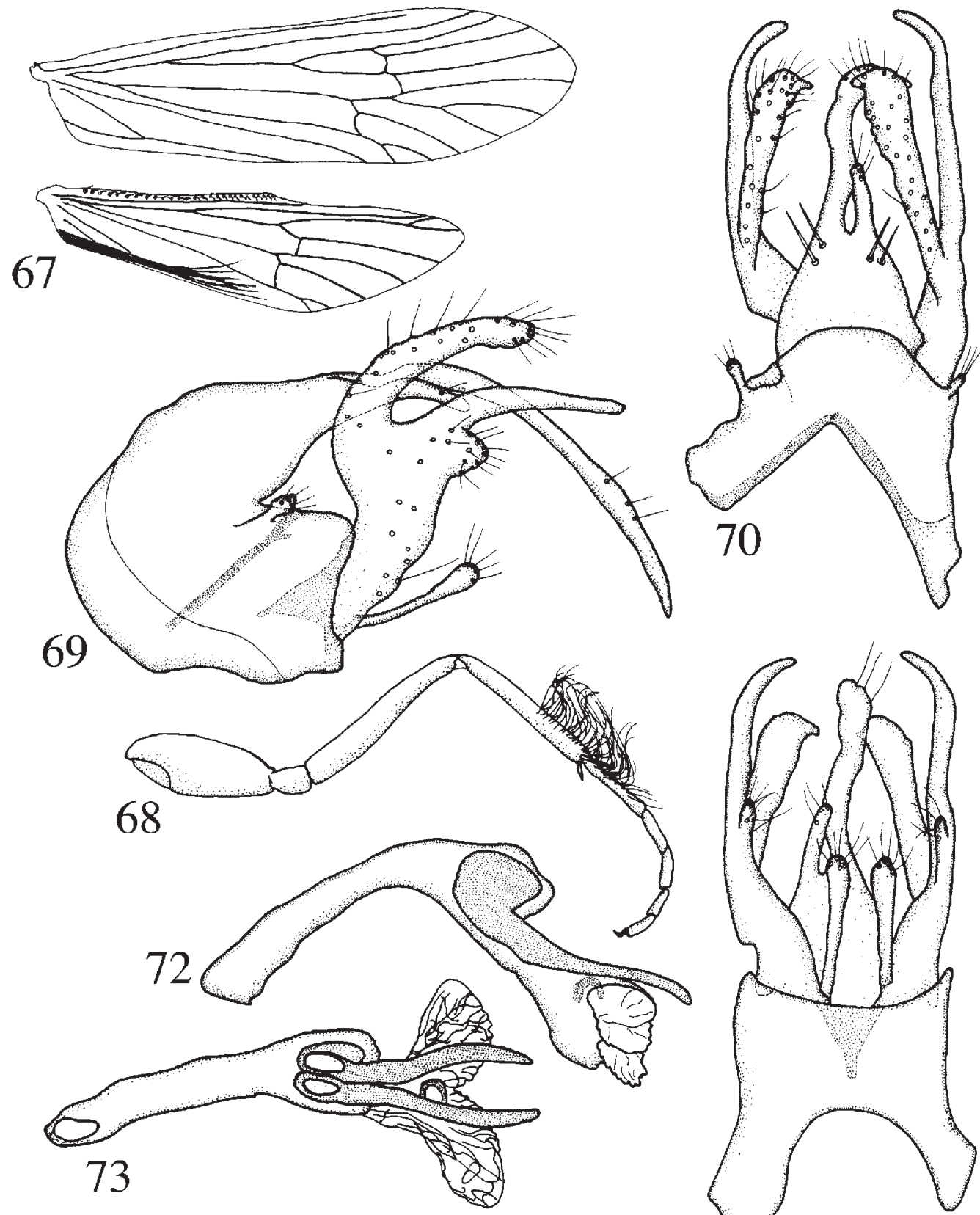

69

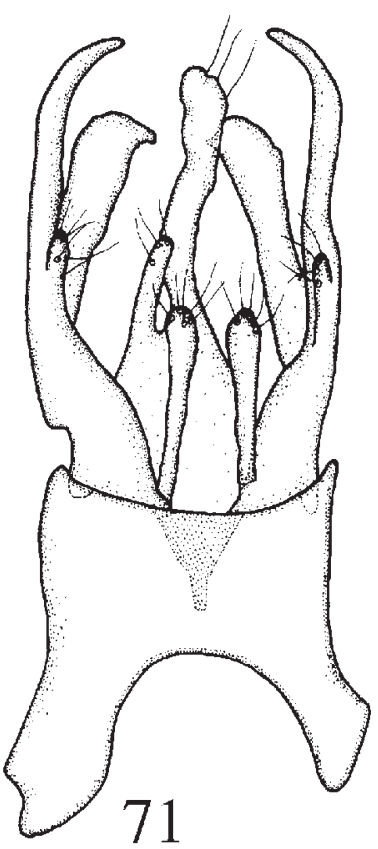

Figs. 67-73. Helicopsyche tenuisa sp. n., male. - 67, right wings; 68, right fore leg, posterior view; 69, genitalia, lateral view; 70, genitalia, dorsal view; 71, genitalia, ventral view; 72, phallus, lateral view; 73, phallus, dorsal view. 
Antenna with scape slightly longer than basal joint of maxillary palp; 44 flagellomeres, each with a ring of scaloid setae. Cephalic warts bean shaped, with grey median lamella covering base formed by long, dark setae. Fore leg posterior spur about ${ }^{1}{ }_{3} \times$ anterior spur. Wings (fig. 62): Fore wing $5.1 \mathrm{~mm}$; crossvein $\mathrm{R}_{3}-\mathrm{R}_{4}$ absent; $M_{2}$ slightly longer than $2 \times$ distal part of $M_{1+2}$; crossvein $\mathrm{M}-\mathrm{Cu}$ meets $\mathrm{Cu}_{1}$ at some distance basally to bifurcation, the distance is about $1.6 \times$ longer than $\mathrm{Cu}_{1 \mathrm{~b}}$ length. Hind wing $4.1 \mathrm{~mm} ; 26$ hamuli; crossvein $\mathrm{M}-\mathrm{Cu}$ fuses with $\mathrm{Cu}_{1}$ on fork $5 ; \mathrm{R}_{2}$ about $1.5 \times$ longer than $\mathrm{R}_{2+3}$. Anal area with brush of long, blackish setae; long curled setae present on distal half; posterior margin with row of very long setae. Genitalia (figs. 63-66): IXth segment expanded anteriad (fig. 65); submarginal apodeme absent; dorsal margin substraight (fig. 65); sternal incision absent; in dorsal view (fig. 64), widely divided. Superior appendage strongly club shaped (fig. 65); originates close to lateral apodeme and directed posteroventral. Xth tergum slender and tapers towards apex (fig. 65); with four pairs long, tuboid, blackish megasetae (figs. 64, 65); apex cleaved halfway toward base (fig. 66). Gonocoxite divides at distal half into a broad, short and posteriorly curved primary branch and a short, slender, substraight secondary branch (fig. 65). Primary branch curves medially and covers Xth tergum. Basal part expanded into rounded process (fig. 66). Basomedian branches fuse basally, short and slightly curved laterally towards apex (fig. 66). Additional pair of small processes present dorsally on gonocoxal base (fig. 66). Basal plate long, tapering and with pointed anterior apex (fig. 66). Phallus (fig. 63) basally and distally substraight; bent ventrad about midway.

Female, larva and pupa. - Unknown.

\section{Helicopsyche tenuisa sp. n. (figs. 67-73)}

\section{Type material}

Holotype, ô (in Canada balsam), NEW CALEDONIA: Riviére Bleue, 166³7'53”E, 255'30"S, 8.xi.1986, UV trap (R. Brown \& O. Pellmyr) (NMNH).

Paratypes, 3 ô (in alcohol), as holotype (NMNH).

\section{Diagnosis}

H. tenuisa sp. n. can be distinguished from other Helicopsyche species by a row of long, dark setae present on the fore leg tibia and first tarsal joint (fig. 68); the asymmetrical, slender Xth tergum (figs. 69-71); the two pairs of basal and three pairs of distal Xth tergal setae (figs. 69, 70); the gonocoxal secondary branch (fig. 69) with a large ventral process; the sick- le shaped primary branch of gonocoxite (fig. 69); the long, slender basomedian branch of gonocoxite (figs. $69,71)$; and the very long phallic sclerous processes (figs. 72, 73).

\section{Etymology}

H. tenuisa, from Latin, tenuis, thin, slender, refers to the shape of the genitalic structures Xth tergum and gonocoxal primary, secondary and basomedian branches.

\section{Description}

Male. - Head: Maxillary palp basal joint longer than distal joint. Antenna with scape as long as basal joint of maxillary palp; with 36 flagellomeres. Cephalic warts large, pyriform and projected towards the anterior head margin. Wings (fig. 67): Fore wing $3.2 \mathrm{~mm}$; fork 1 originates distally on Dc; Dc about $1.4 \times$ longer than $\mathrm{M}_{2} ; \mathrm{M}_{2}$ about $1.4 \times$ longer than distal part of $\mathrm{M}_{1+2}$; crossvein M-Cu meets $\mathrm{Cu}_{1}$ at some distance basally to bifurcation of $\mathrm{Cu}_{1}$, the distance being equal to $\mathrm{Cu}_{1 \mathrm{~b}}$ length; crossvein $\mathrm{Cu}_{1}-\mathrm{Cu}_{2}$ absent. Hind wing $2.6 \mathrm{~mm}$; with 27 hamuli; crossvein $\mathrm{M}-\mathrm{Cu}$ meets $\mathrm{Cu}_{1}$ at long distance before fork 5; $\mathrm{R}_{2}$ nearly half as long as $\mathrm{R}_{2+3}$; group of long, dark setae originates from anal area. Posterior spur of fore leg about ${ }_{3}{ }_{3} \mathrm{X}$ anterior spur; dorsal margin of tibia and $1^{\text {st }}$ tarsal segment with dense, long, dark setae in row (fig. 68). VIth sternal process absent. Genitalia (figs. 69-73): IXth segment rounded anteriorly (fig. 69); asymmetrical (figs. 70, 71); submarginal apodeme apparently present on left half (fig. 69); sternal incision absent. Superior appendage, short, club shaped, originates close to lateral apodeme (figs. 69, 70). Xth tergum asymmetrical, with right side about $3 \times$ longer than left side (figs. 69, 70, 71); slightly curved ventrad along its length (fig. 69); without megasetae; with two pairs of basal setae and about three pairs of apical setae (figs. 69, 70); apex rounded (fig. 71). Gonocoxite with slender primary and secondary branches (fig. 69); primary branch about $2 \times$ broader than secondary branch (fig. 69); in lateral view slightly curved posteriad. Basal process broad, rounded in lateral view (fig. 69), slender in ventral view (fig. 71), originates basiventrally on secondary branch (fig. 69). Basomedian branch long, slender, club shaped and substraight (figs. 69, 71). Basal plate short; anteriorly thin and with rounded apex (fig. 71). Phallus basally and distally substraight, mid part bent ventrad (fig. 72); basal part thinner than distal part (fig. 73); with a pair of very long, basally broad and distally slender sclerous processes (figs. 72, 73).

Female, larva and pupa. - Unknown. 


\section{H. patriciae sp. n.}

(figs. 74-78)

\section{Type material}

Holotype, $\hat{0}$ (in alcohol), NEW CALEDONIA: 5 $\mathrm{km}$ S Touho, 100m, Panandou River, 165¹3'E,
2049’S, 2.ii.1984 (M. Pogue \& M. Epstein) (NMNH).

\section{Diagnosis}

$H$. patriciae sp. n. can be distinguished from other Helicopsyche species by the ovoid gonocoxal primary
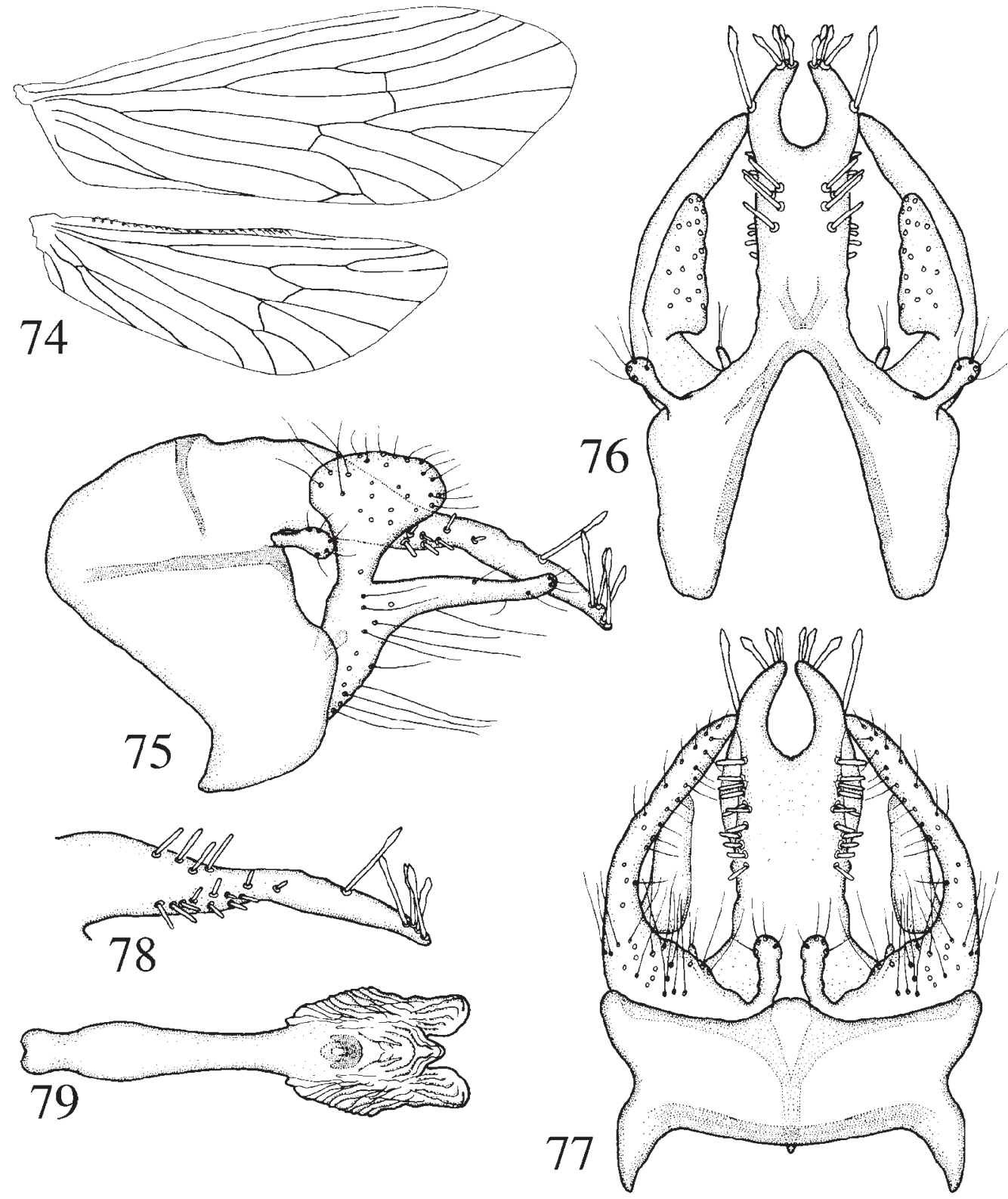

Figs. 74-79. Helicopsyche patriciae sp. n., male. - 74, right wings; 75, genitalia, lateral view; 76, genitalia, dorsal view; 77, genitalia, ventral view; 78, Xth tergum, lateral view; 79, phallus, dorsal view. 
branch (fig. 75); the long Xth tergum which has central rows of short, tuboid megasetae and apical, drop shaped megasetae (figs. 75, 76, 77); and a pair of tiny additional process originating dorsally on the basal part of the gonocoxite (figs. 75, 76, 77).

\section{Etymology}

H. patriciae, named after Mrs. Patricia W. Schefter in recognition of her enthusiasm for NEW CALEDONIAn Helicopsyche.

\section{Description}

Male. - Head maxillary palp joints about equally long. Antenna: scape about as long as basal joint of maxillary palp; with 42 flagellomeres. Cephalic warts strongly pyriform, reach anterior head margin. Fore
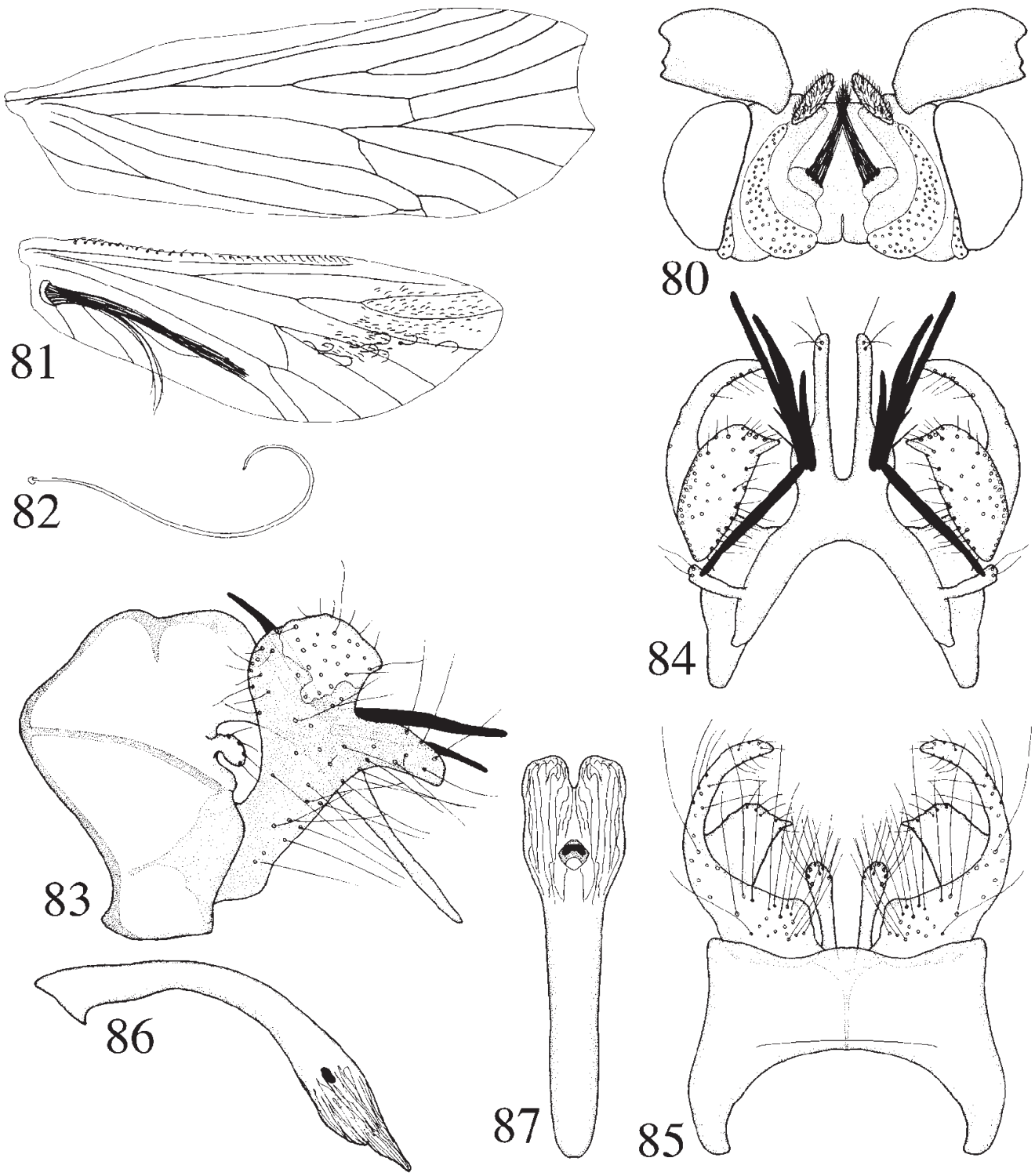

Figs. 80-87. Helicopsyche nigrospinosa sp. n., male. -80 , head, dorsal view; 81, right wings; 82, curled seta from hind wing, highly magnified; 83 , genitalia, lateral view; 84 , genitalia, dorsal view; 85 , genitalia, ventral view; 86 , phallus, lateral view; 87 , phallus, ventral view. 
leg posterior spur length about half anterior spur length. Wings (fig. 74): Fore wing $4.6 \mathrm{~mm}$; fork 1 originates distally on Dc; Dc about $1.6 \times$ longer than $\mathrm{M}_{2} ; \mathrm{M}_{2}$ about $2 \times$ longer than distal part of $\mathrm{M}_{1+2}$; crossvein $\mathrm{M}-\mathrm{Cu}$ meets $\mathrm{Cu}_{1}$ at some distance before bifurcation of $\mathrm{Cu}_{1}$, the distance being about as long as $\mathrm{Cu}_{1 \mathrm{~b}}$; crossvein $\mathrm{Cu}_{1}-\mathrm{Cu}_{2}$ present. Hind wing $3.5 \mathrm{~mm}$; with 22 hamuli; crossvein $\mathrm{M}-\mathrm{Cu}$ meets basal part of fork 5; $\mathrm{R}_{2}$ slightly longer than $\mathrm{R}_{2+3}$. Modified setae $\mathrm{ab}-$ sent. VIth sternal process well developed. Genitalia (figs. 75-78): IXth segment anteriorly hyperbeloid; without submarginal apodeme; sternal incision wide, not deep. Superior appendage originates close to lateral apodeme (fig. 75); directed postero-laterad, club shaped. Xth tergum substraight, slender in lateral view (fig. 75), broad in ventral and dorsal views (figs. 76, 77); with about eleven pairs of short megasetae arranged in ventrolateral row (fig. 77); three pairs of long, tuboid megasetae form a row midway on segment (fig. 76); a pair of long dorsal, posterodorsad, drop shaped preapical megaseta (figs. 75, 77); a group of four drop shaped, long apical megasetae (figs. 75, 76, 77). Gonocoxite with short, apically subcircular primary branch, and long, thin and substraight secondary branch (fig. 75). Broad basal part without projections but with a pair of $\mathrm{v}$ ery small processes originating from dorsal face (figs. 75, 77). Basomedian branches medially long, tuboid and substraight (fig. 77). Basal plate anteriorly produced, slender, pointed. Phallus (fig. 78) substraight, with basal part slightly swollen; without sclerous processes.

Female, larva and pupa. - Unknown.

\section{Helicopsyche nigrospinosa sp. $\mathrm{n}$. \\ (figs. 80-87)}

\section{Type material}

Holotype, o (in alcohol), NEW CALEDONIA: Mt. Koghi, 400m, 12-14.xi.1986, UV trap (R. Brown \& O. Pellmyr) (NMNH).

\section{Diagnosis}

H. nigrospinosa sp. n. can be distinguished from other Helicopsyche species by the hind wing setae which include a brush of long, dark setae in the anal area; long curled setae in $\mathrm{R}_{5}$ - and distal part of the $\mathrm{M}$ sectors and small scaloid setae in the distal part of the radial and median sectors (fig. 81); the dorsally produced IXth tergal margin (fig. 83); the laterally expanded Xth tergum (fig. 84); the elongate and strongly tapering Xth tergum (fig. 83); and the long, club shaped gonocoxal basomedian branches (fig. 85).

\section{Etymology}

$H$. nigrospinosa, from Latin, nigro, blackish, spinosus, thorny, refers to the long, dark Xth tergal megasetae.

\section{Description}

Male. - Head (fig. 80): Maxillary palp joints equally long. Antenna: scape as long as basal joint of maxillary palp; flagella broken. Cephalic wart sicle shaped, elongated anteriorly; grey curved lamella originates from median part of cephalic warts; grey process with long, dark setae present between the grey lamellae. Interantennal warts present, covered by short setae. Posterior spur length of fore leg about half of anterior spur length. Wings (figs. 81, 82): Fore wing $5.0 \mathrm{~mm}$; crossvein $\mathrm{R}_{2}-\mathrm{R}_{3}$ absent; $\mathrm{M}_{2}$ about $2.6 \times$ longer than distal part of $\mathrm{M}_{1+2}$; Crossvein $\mathrm{M}-\mathrm{Cu}$ meets $\mathrm{Cu}_{1}$ at some distance basally to fork 5 , the distance is about $2 \times \mathrm{Cu}_{1 \mathrm{~b}}$ length. Hind wing $4.1 \mathrm{~mm}$; with 31 hamuli; crossvein $\mathrm{M}-\mathrm{Cu}$ fuses with fork $5 ; \mathrm{R}_{2}$ nearly $1.9 \times$ longer than $\mathrm{R}_{2+3}$. Anal area with brush of long, dark setae. Short lamelloid and long, thin curled setae (fig. 82) present on distal half. VIth sternal process large. Genitalia (figs. 83-87): IXth segment anteriorly rounded (fig. 83); submarginal apodeme absent; dorsal margin with dorsal projection (fig. 83); sternal incision wide, shallow (fig. 83). Superior appendage originates at some distance dorsally to lateral apodeme tuboid, directed laterad (fig. 84). Xth tergum substraight, tapering towards apex, slender in lateral view (fig. 83); in dorsal view (fig. 84), with broad central part, apex slender and deeply divided; four pairs of long, dark, tuboid megasetae originate from dorsal central part (figs. 83, 84). Gonocoxite with basal part long and broad; divided medially into broad, anterodorsally rounded, slightly posteriorly pointed primary branch, and a broad, slightly ventrad curved secondary branch (fig. 83); slightly produced into a pair of small rounded processes (fig. 85). Basomedian branches long, club shaped, substraight (fig. 85). Basal plate long, anteriorly needle shaped (fig. 85). Phallus without sclerous processes (figs. 86, 87), slightly curved ventrad along its length (fig. 86), anterior part and posterior part equally broad (fig. 87).

Female, larva and pupa. - Unknown.

\section{Helicopsyche livida sp. n.}

(figs. 88-93, 95)

\section{Type material}

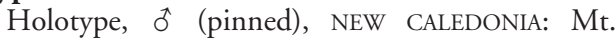
Panié, 250m, 30.x.1986, Malaise trap (R. Brown \& O. Pellmyr) (NMNH).

\section{Diagnosis}

H. livida sp. n. can be distinguished from other Helicopsyche species by the Xth tergum with a group 
of long, tuboid megasetae, row of central setae, a long, lateral, tuboid, subapical megaseta, and tuboid, dorsal megasetae (figs. 89, 91, 92); the rounded gonocoxal primary branch (fig. 89); and the additional tuboid basal branches on the gonocoxite (fig. 92).

\section{Etymology}

H. livida, from Latin, lividus, bluish, refers to the bluish wing spots which appearing in sunlight.

\section{Description}

Male. - Head unknown. Fore wing (fig. 88): 5.0 $\mathrm{mm} ; \mathrm{M}_{2}$ about $5 \times$ longer than distal part of $\mathrm{M}_{1+2}$.
Hind wing $3.7 \mathrm{~mm}$. Fore wing dark brownish, silver blue or metallic green/purple in sunlight depending on light angle. Three whitish areas present: a band in R-section, a band crossing distal part of $\mathrm{Cu}$, and a small basal spot in A-section, all being silver bluish in sunlight. Posterior wing colour grey-brownish. Genitalia (figs. 89-93): IXth segment anterior part hyperbolic, submarginal apodeme absent, but with a line running between dorsal margin of IXth tergum and ventral margin of IXth sternum (fig. 89); dorsal margin slightly convex; sternal incision small, wide; ventral sternal margin with rounded notch (fig. 89), seen
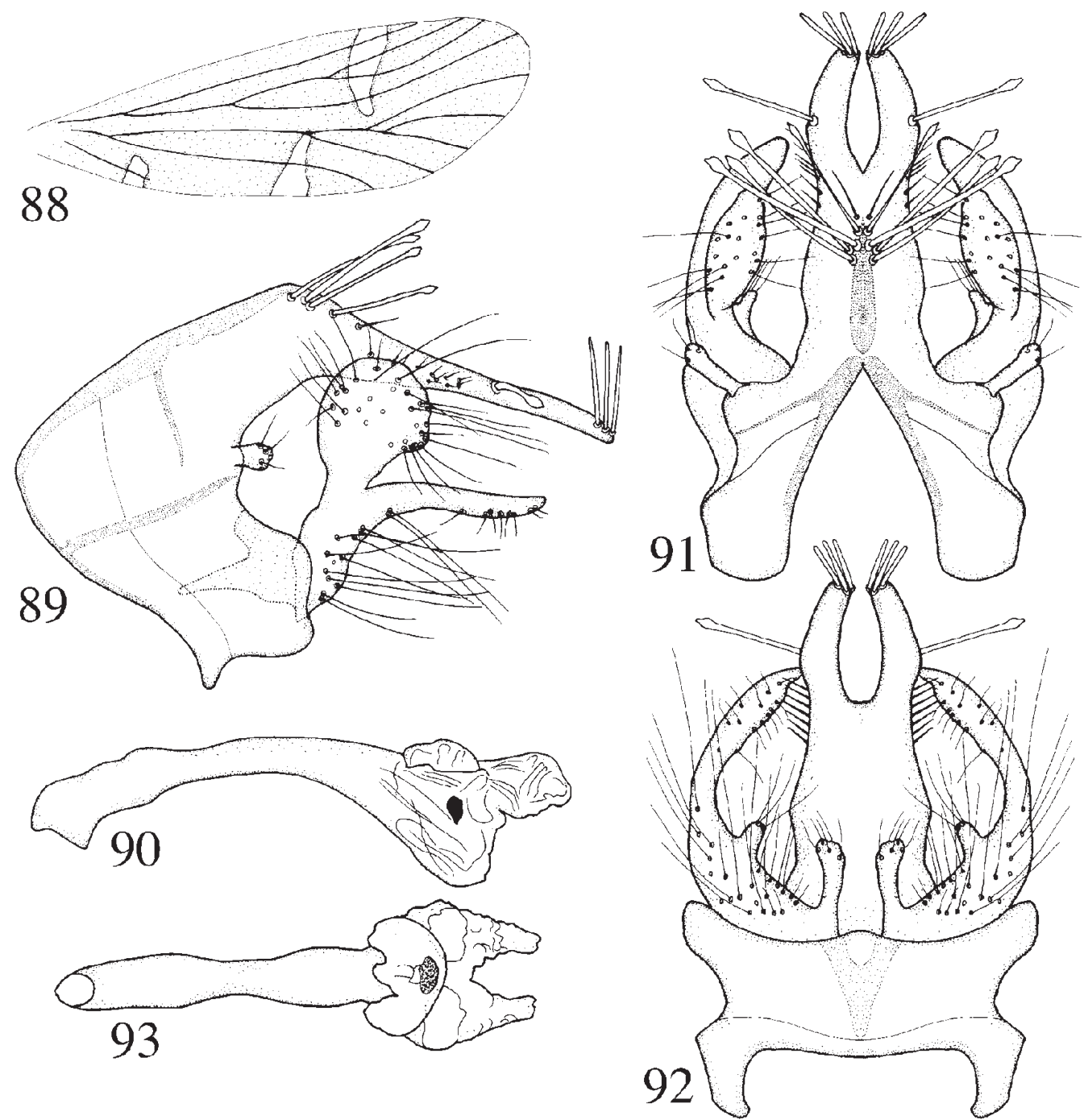


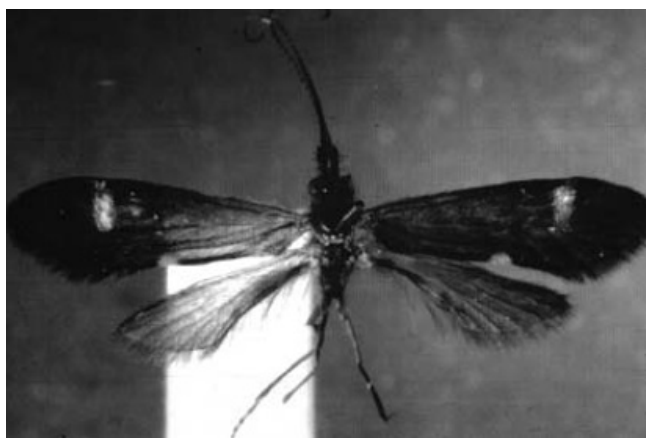

Fig. 94. Helicopsyche arma sp. n., male holotype, dorsal view.

also in dorsal and ventral views (figs. 91, 92). Superior appendage originates close to lateral apodeme (fig. 89). Xth tergum slightly tapering towards apex (fig. 88); with broad lateral undulations (figs. 91, 92); basal part with four pairs long, drop shaped megasetae; central part with short setae arranged in row; a pair of laterad and drop shaped subapical megasetae, and a group encompassing three pairs of shorter tuboid megasetae at apex. Gonocoxite with long basal part; divides into a short, rounded primary branch and a slender, substraight secondary branch (fig. 89); basal part (fig. 92) with short, tuboid process. Basomedian branches short, substraight and slightly club shaped (fig. 92). Basal plate short, tapering anteriorly (fig. 92). Phallus slightly curves ventrad; without sclerous processes; anteriorly wide; central part narrowing; posterior part as wide as anterior part (figs. 90, 93).

Female, larva and pupa. - Unknown.

\section{Helicopsyche rembaia sp. $n$.}

(figs. 96-101)

\section{Type material}

Holotype, ô (in Canada balsam), NEW CALEDONIA: Mt. Rembai, 750 m, 24-29.x.1981 (G. W. Gibbs) (IHPC).

\section{Diagnosis}

Male $H$. rembaia sp. n. is distinguished from other Helicopsyche species by the Xth tergum which is slender in lateral view (fig. 97); the basomedian branches that are slightly shorter than the breadth of the gonocoxal primary branches (fig. 97); the broad, substraight primary gonocoxal branches (fig. 97); and the endotheca which is produced into two dorsal, apically dark pigmented lobes (fig. 100).

\section{Etymology}

H. rembai, after the type locality.

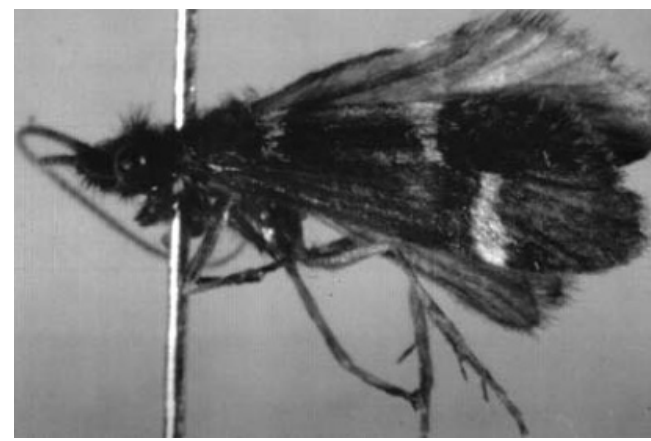

Fig. 95. Helicopsyche livida sp. n., male holotype, lateral view.

\section{Description}

Male (figs. 96-101). - Head: distal joint of maxillary palp slightly longer than basal joint; scape about as long as basal joint of maxillary palp; flagella broken. Cephalic warts strongly pyriform, extended towards anterior head margin. Interantennal warts absent. Wings (fig. 96): Fore wing $4.6 \mathrm{~mm}$; fork 1 originates about midway on Dc; Dc nearly $2 \times$ longer than $M_{2} ; M_{2}$ nearly $2 \times$ longer than distal part of $\mathrm{M}_{1+2}$; crossvein $\mathrm{M}$-Cu meets $\mathrm{Cu}_{1}$ at a distance before bifurcation of $\mathrm{Cu}_{1}$; Crossvein $\mathrm{Cu}_{1}-\mathrm{Cu}_{2}$ present. Posterior wing $3.6 \mathrm{~mm}$; with 28 hamuli; $\mathrm{R}_{2+3}$ about $3.3 \times$ longer than $\mathrm{R}_{2}$; Crossvein $\mathrm{M}-\mathrm{Cu}$ meets $\mathrm{Cu}_{1}$ at some distance into $\mathrm{Cu}_{1 \mathrm{a}}$; scaloid setae and long, dark setae absent. Fore leg posterior spur length about $0.5 \times$ anterior spur length. Abdomen with VIth sternal process well developed. Genitalia (figs. 97-101): IXth segment produced anterodorsad, submarginal apodeme absent (fig. 97). IXth sternal incision wide (fig. 97). Superior appendage directed posteriad and originates at some distance dorsally to lateral apodeme. Xth tergum, lateral view, substraight, slender (fig. 97). Xth tergal megasetae thin, forming two lateral rows. Xth tergum dorsal margin about parallel with ventral margin in lateral aspect, apex rounded (fig. 97). Gonocoxal primary branch about $2 \times$ broader than secondary branch in lateral aspect (fig. 97); substraight, with anterior and dorsal margins subparallel. Secondary branch curved mediad, apex pointed (fig. 99); basally broad, not produced medially (fig. 99). Basomedian branch, lateral view, short, slightly club-shaped (fig. 97); in ventral view, parallel sided, substraight (fig. 99). Basal plate tapers anteriorly (fig. 99). Phallus (figs 100, 101) without sclerous processes, but with a pair of dorsal membranous lobes that are darkly pigmented at apex; in ventral view, basally slender, slightly broader towards apex; curved ventrad at about half its length.

Female, larva and pupa. - Unknown. 


\section{Helicopsyche unilobata sp. n.}

(figs. 102-107)

\section{Type material}

Holotype, ô (in Canada balsam), NEW CALEDONIA: Forêt Thy Reserve, 21.v.1984, 150m (G. Monteith \& D. Cook) (CM).

\section{Diagnosis}

Male H. unilobata sp. $\mathrm{n}$. is distinguished from other Helicopsyche species by the simple gonocoxite; the Xth tergum which is slender in lateral aspect (fig. 103 ), and has a hook shaped process ventrally on apex; short, slender dorsal megasetae in two groups; and the short, laterally oriented superior appendages.

\section{Etymology}

H. unilobata, after the unilobed gonocoxite.

\section{Description}

Male (figs. 102-107). - Head: joints of maxillary palp about equally long; scape about as long as basal joint of maxillary palp; flagella broken. Cephalic warts bean shaped. Interantennal warts apparently absent. Wings (fig. 102): Fore wing $4.0 \mathrm{~mm}$; fork 1 originates from the distal corner of Dc; Dc about as long as $\mathrm{M}_{2}$ and distal part of $\mathrm{M}_{1+2}$; crossvein $\mathrm{M}-\mathrm{Cu}$ meets $\mathrm{Cu}_{1}$ at a distance before bifurcation of $\mathrm{Cu}_{1}$, the distance is slightly longer than the $\mathrm{Cu}_{1 a}$ length; Crossvein $\mathrm{Cu}_{1}-\mathrm{Cu}_{2}$ apparently absent. Posterior wing $3.1 \mathrm{~mm} ; 24$ hamuli; $\mathrm{R}_{2+3}$ about as long as $\mathrm{R}_{2}$; Crossvein $\mathrm{M}-\mathrm{Cu}$ nearly tangent to point of bifurca-

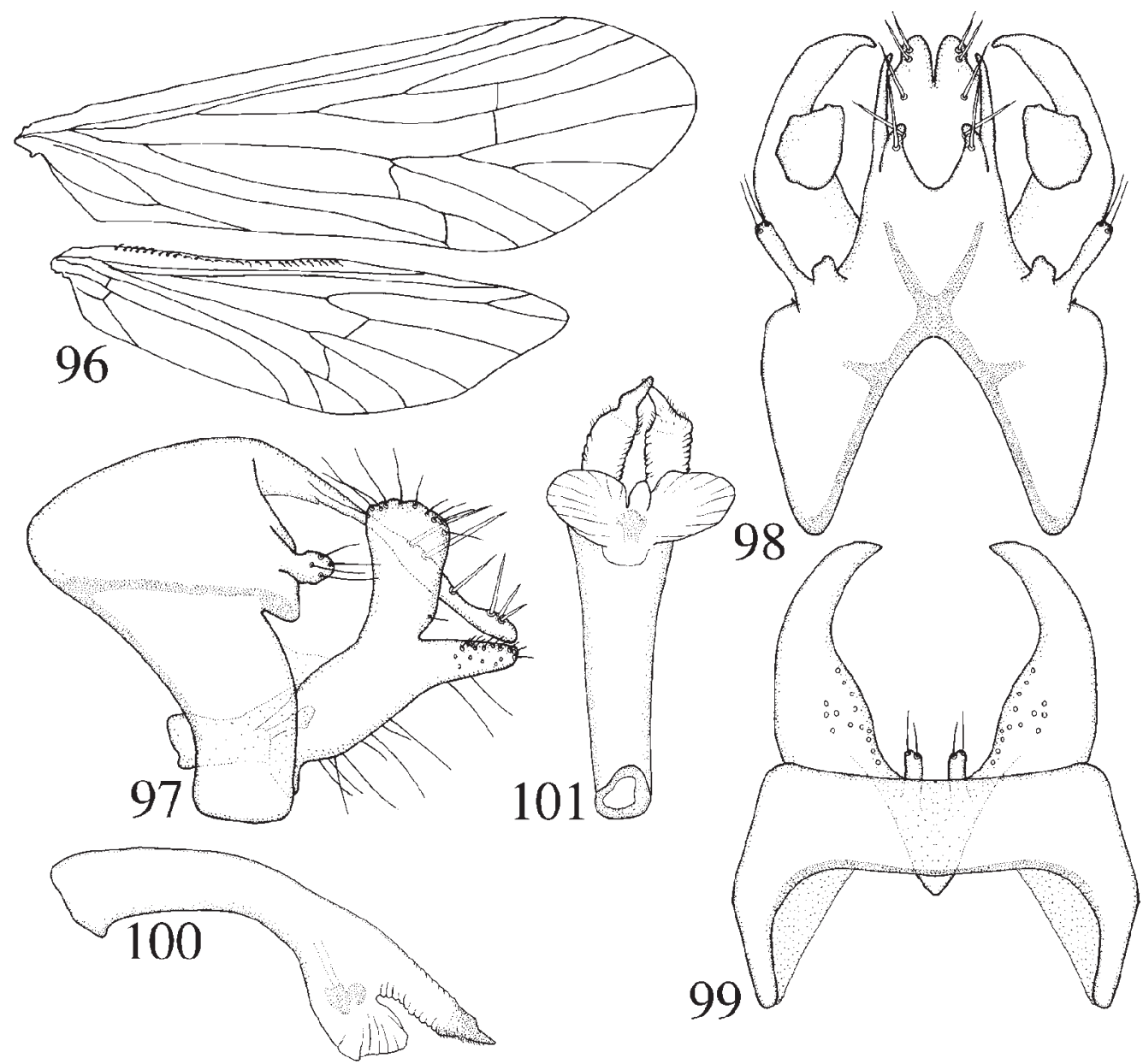

Figs. 96-101. Helicopsyche rembai sp. n., male. - 96, right wings; 97, genitalia, lateral view; 98, genitalia, dorsal view; 99, genitalia, ventral view; 100, phallus, lateral view; 101, phallus, ventral view. 
tion of $\mathrm{Cu}_{1}$; brush of long, dark anal setae present. Scaloid setae scattered over the surfaces of both fore and hind wings. Fore leg posterior spur length about $1 / 2 \times$ anterior spur length. Abdomen with VIth sternal process well developed. Genitalia (figs. 103-107): IXth segment produced anterodorsad, submarginal apodeme absent (fig. 103). IXth sternal incision small and (fig. 103). Superior appendage originates at some distance dorsally to lateral apodeme and is directed laterad. Xth tergum, lateral view, slender, slightly curved ventrally (fig. 103). Xth tergal megasetae short, slen- der, present in two groups (fig. 104). Xth tergum dorsal margin about parallel with ventral margin in lateral aspect, apex rounded in dorsal view; with hook shaped processes in ventral view (fig. 105). Gonocoxal primary branch oval in lateral view (fig. 103). Secondary branch absent (fig. 103). Basomedian branch, ventral view, short and parallel sided (fig. 103). Basal plate anteriorly tapering (fig. 105). Phallus (figs. 106, 107) without sclerous processes, but with pair of dorsal lobes with dark pigmented apex; ventral view, parallel sided; curved ventrad at about half its length.

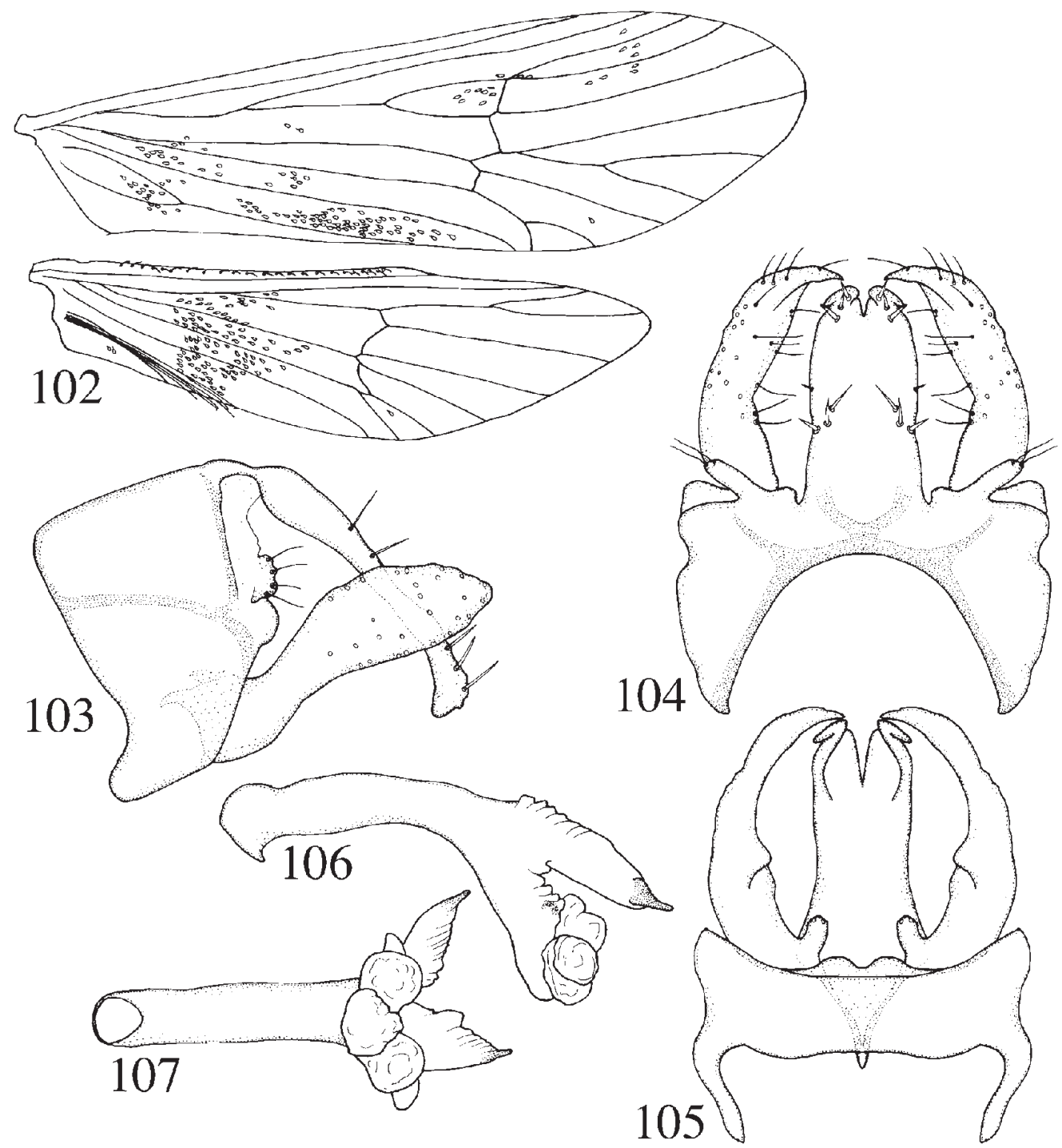

Figs. 102-107. Helicopsyche unilobata sp. n., male. - 102, right wings; 103, genitalia, lateral view; 104, genitalia, dorsal view; 105 , genitalia, ventral view; 106 , genitalia, lateral view; 107, genitalia, ventral view. 
Female, larva and pupa. - Unknown.

\section{Helicopsyche gibbsi sp. n.}

(figs. 108-114)

\section{Type material}

Holotype, ơ (in Canada balsam), NEW CALEDONIA: Mt. Rembai, 570m, 24-29.x.1981 (G. W.
Gibbs) (IHPC). Paratype, 10 (in alcohol), NEW CALEDONIA: Mt. Rembai, 30.xi.1978 [G. W. Gibbs] (IHPC).

\section{Diagnosis}

Male $H$. gibbsi sp. n. are distinguished from other Helicopsyche species by the gonocoxite having a very broad primary branch and slender secondary branch (fig. 109); slender, substraight Xth tergum (fig. 110); single pairs of megasetae apically on the Xth tergum

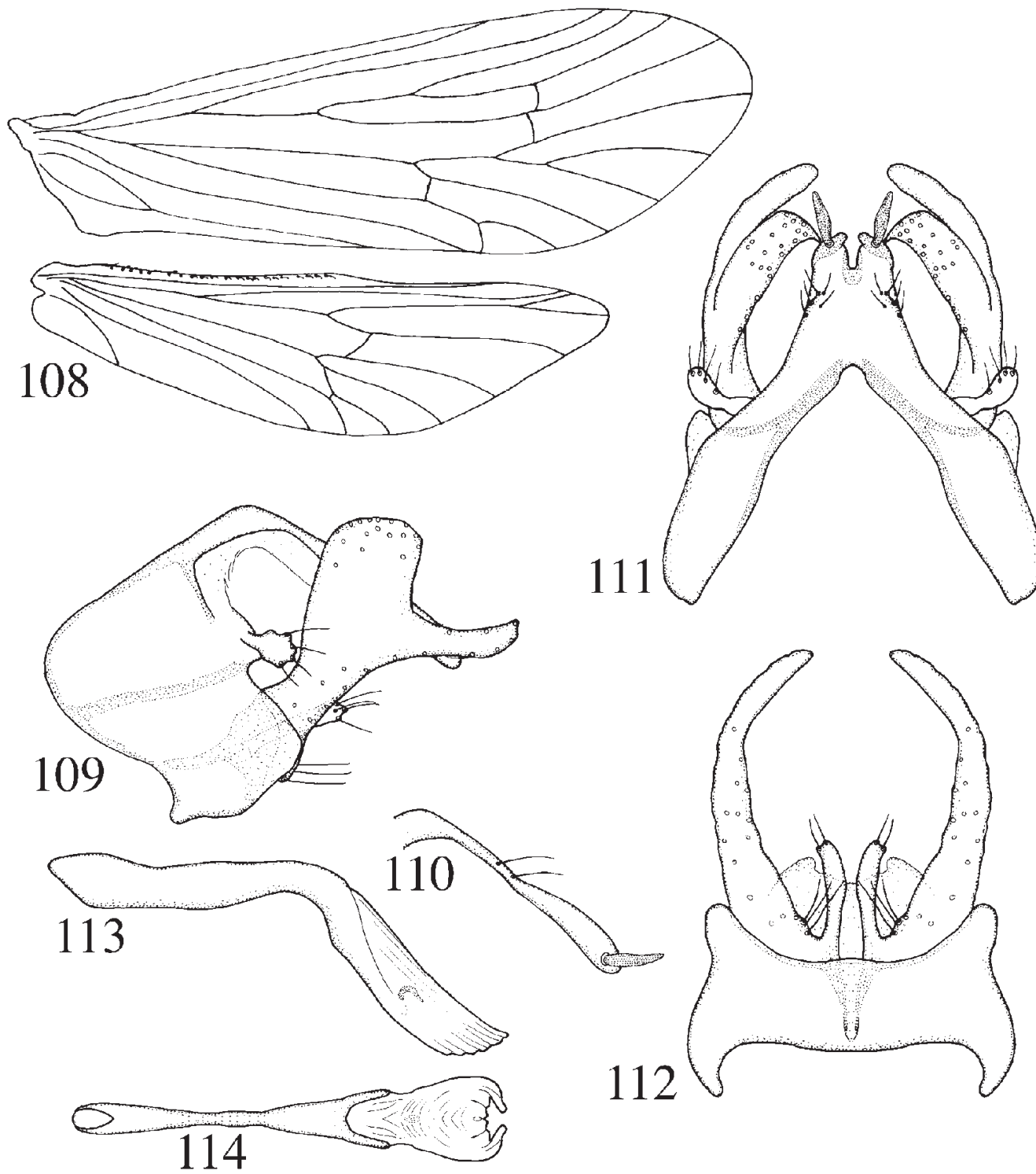

Figs. 108-114. Helicopsyche gibbsi sp. n., male. - 108, right wings; 109, genitalia, lateral view; 110, Xth tergum, lateral view; 111, genitalia, dorsal view; 112, genitalia, ventral view; 113, phallus, lateral view; 114, phallus, ventral view. 
(figs. 110-111); long, tuboid basomedian branches (fig. 112); and the laterad superior appendages (fig. 111).

\section{Etymology \\ H. gibbsi, after the collector, G. W. Gibbs.}

\section{Description}

Male (figs. 108-114). - Head: joints of maxillary palp equally long. Antenna: scape about as long as basal joint of maxillary palp; with 36 flagellomeres. Cephalic warts strongly pyriform, extended towards anterior head margin. Interantennal warts apparently absent. Wings (fig. 108): Fore wing $3.5 \mathrm{~mm}$; fork 1 originates about midway on Dc; Dc nearly $2 \times$ longer than $\mathrm{M}_{2} ; \mathrm{M}_{2}$ about $2 \times$ longer than distal part of $\mathrm{M}_{1+2}$; crossvein $\mathrm{M}-\mathrm{Cu}$ meets $\mathrm{Cu}_{1}$ at a distance before bifurcation of $\mathrm{Cu}_{1}$, this distance is which is about equal to the length of $\mathrm{Cu}_{12}$; Crossvein $\mathrm{Cu}_{1}-\mathrm{Cu}_{2}$ apparently absent. Posterior wing $2.8 \mathrm{~mm} ; 21$ hamuli; $\mathrm{R}_{2+3}$ about $4 \times$ longer than $\mathrm{R}_{2}$; Crossvein $\mathrm{M}-\mathrm{Cu}$ nearly meets point of bifurcation of $\mathrm{Cu}_{1}$; scaloid setae and brush of long, dark anal setae absent. Fore leg posterior spur length about ${ }^{1}{ }_{3} X$ anterior spur length. Abdomen with VIth sternal process well developed. Genitalia (figs. 109-114): IXth segment produced anterodorsad, submarginal apodeme absent (fig. 109). IXth sternal incision small and U-shaped (fig. 109). Superior appendage originates close to lateral apodeme, oriented laterad. Xth tergum, lateral view, straight and slender (figs. 109, 110); megasetae present apically are dark and knife-shaped (figs 109, 110 ); dorsal margin about parallel with ventral margin, apex rounded (fig. 108). Gonocoxal primary branch about $4 \times$ broader than secondary branch in lateral view (fig. 109); substraight and dorsally rounded (fig. 109); slightly shorter than secondary branch. Secondary branch curved mediad, apex slightly rounded (fig. 109); slender basal part lack processes (fig. 112). Basomedian branch slightly club-shaped (fig. 109); in ventral view, basally parallel sided and substraight, distally bent laterad (fig. 112). Basal plate anteriorly pointed (fig. 112). Phallus (figs. 113, 114) without sclerous processes; in lateral view with basal part as broad as median part; angled ventrad at about half length.

\section{Key to new Caledonian Helicopsyche, males}

For comparison with the previously described NEW CALEDONIAn Helicopsyche species refer to Ross (1975) and Johanson and Schefter (1999).

1. Xth tergal megasetae absent (as in fig. 15) ....... 2

- Xth tergal megasetae present (as in fig. 7) ........ 9

2. Xth tergum simple (as in figs 7,15 ) ..................
- Xth tergum with additional basolateral processes (figs. 20, 98) ..................................................... 6

3. Xth tergum curves ventrally along its length in lateral view (fig. 69)

- Xth tergum substraight in lateral view (fig. 103)

4. Gonocoxite undivided (fig. 103); Xth tergum with more that two pairs of basal setae (fig. 104) H. unilobata sp. n.

- Gonocoxite divides into primary and secondary branches (fig. 69); Xth tergum with two pairs of basal setae (fig. 70) ...........................................27

5. Cephalic warts circuloid; postantennal warts absent; posterior wings with long curled setae on basal half (fig. 56); Xth tergum broad in dorsal and lateral view (figs. 57, 60); primary branch of gonocoxite sickle shaped in lateral view; basomedian branch of gonocoxite short (fig. 61); phallus with two pairs of small processes (fig. 58)

H. fusca sp. n.

- Cephalic warts pyriform; postantennal warts present; posterior wings without curled setae; Xth tergum slender in dorsal and lateral view; primary branch of gonocoxite slightly curved in lateral view; basomedian branch of gonocoxite long; phallus with one pair of process-like processes ....

H. kariona Ross

6. Xth tergum additional processes as long as, or longer than apex of Xth tergum (figs. 46, 49)

- Xth tergum additional processes shorter than Xth tergum (figs. 20, 98) ......................................... 8

7. Primary branch of gonocoxite angled about $90^{\circ}$; posterior pair of phallic processes small

H. arenaria Ross

- Primary branch of gonocoxite smoothly curved (fig. 45); posterior pair of phallic processes large, curved dorsad (fig. 48) ............. H. baroua sp. n.

8. Xth tergum basally erected dorsally (fig. 19); gonocoxite, with slender, sickle shaped primary branch (fig. 19); gonocoxite, with pair of additional medio-marginal processes (fig. 21) ...... 28

- Xth tergum basally not erected dorsally (fig. 97); gonocoxite with broad, rectanguloid primary branch (fig. 97); gonocoxite, without additional marginal processes (fig. 99) ........H. rembai sp. n.

9. Xth tergum expanded dorsally (fig. 7) ..............10

- Xth tergum not expanded dorsally (figs. 65, 83)

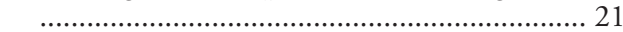

10. IXth segment dorsal margin strongly concave and anterior apex rectanguloid ....................... 11

- IXth segment dorsal margin substraight, or concave (if strongly concave the anterior apex is pointed or rounded) ........................................12

11. IXth segment with submarginal apodeme; IXth segment posteriorly produced into a rounded 
dorsal process; Xth tergum laterally about as broad as the gonocoxal primary branch; basomedian branch of gonocoxite slender in both ventral and lateral view H. lapidaria Ross

- IXth segment without submarginal apodeme; IXth segment posteriorly not produced into a dorsal process; Xth tergum laterally about half as broad as the gonocoxal primary branch; basomedian branch of gonocoxite broad in ventral and lateral view H. starmuehlneri Ross

12. Xth tergum with anterior lobe (fig. 7) $\ldots 13$

- Xth tergum without anterior lobe (figs. 31, 51)

13. Gonocoxal primary branch oriented in right angle to secondary branch (fig. 3) ...................... 14

- Gonocoxal primary branch acute-angled to secondary branch (fig. 39) 16

14. Hind wings fork 1 longer than its stalk; anal region with a brush of long, dark setae; distal half covered by long, curled setae; Xth tergum with three pairs of megasetae ......... H. edmundsi Ross

- Hind wings fork 1 shorter than its stalk (fig. 1); anal region without a brush of long setae (fig. 1); long curled setae absent (fig. 1); Xth tergum with six or more pairs megasetae (fig. 5) .. 15

15. IXth sternum, lateral view, strongly produced anteriad (fig. 3); IXth segment anterior apex nearly rectangular (fig. 3); Xth tergum with six pairs of megasetae (fig. 5); gonocoxite primary branch with sigmoid posterior margin (fig. 3)

H. pellmyrisp. n.

- IXth sternum, lateral view, slightly produced anteriad; IXth segment with nearly rectanguloid anterior apex; Xth tergum with eight pairs of megasetae; gonocoxite primary branch with concave posterior margin .............. H. hollowayi Ross

16. Xth tergum with large anterior lobe (fig. 42); Xth tergum with less than eight pairs megasetae (fig. 40) 17

- Xth tergum with small anterior lobe (fig. 30); Xth tergum with more than eight pairs megasetae (fig. 28) 18

17. Gonocoxal primary branch about half as broad as Xth tergum; in ventral view gonocoxite without median process; basomedian branch of gonocoxite broad in lateral view .......... H. caledonia Ross

- Gonocoxal primary branch about as broad as Xth tergum (fig. 39); in ventral view, gonocoxite with small median process (fig. 43); basomedian branch of gonocoxite slender in lateral view (fig. 39) ......................................... H. browni sp. n.

18. VIth sternal process present; IXth segment strongly produced anteriad from the submarginal apodeme; Xth tergal megasetae in dorso-basal and medio-lateral groups in addition to a single latero-apical seta; basomedian branches of gono- coxite curved laterad H. boularia Ross

- VIth sternal process absent; IXth segment slightly produced anteriad from the submarginal apodeme (fig. 25); Xth tergal megasetae in large dorso-basal group in addition to a single lateroapical seta (figs 28, 30); basomedian branches of gonocoxite straight in ventral view (fig. 29) .......

H. rossisp. n.

19. IXth sternum in lateral view not incised; Xth tergum, with dorsal rhomboid process; gonocoxite basal plate anteriorly pointed; basomedian branches of gonocoxite originate close to each other H. petersorum Ross

- IXth sternum, lateral view, strongly incised (fig. 31); Xth tergum without dorsal process (fig. 31); gonocoxite basal plate rounded or truncate (figs. 34, 54); basomedian branches of gonocoxite originate distantly to each other ........................... 20

20. IXth segment with about parallelogram shaped anterior part (fig. 31); IXth tergite without dorsal process (fig. 31); IXth tergite, dorsal view, with median margin concave (fig. 33); Xth tergum with long megasetae (figs. 33, 36); Xth tergum basoventral margin concave (fig. 36); gonocoxite, ventral view, with basomedian margin produced into a large, pointed process (fig. 34); basomedian branches strongly diverging (fig. 34)

H. neocaledonia sp. n.

- IXth segment with about trianguloid anterior part (fig. 51); IXth tergite with rounded dorsal process (fig. 51); IXth tergite, dorsal view, with broad process on median margin (fig. 55); Xth tergum with short megasetae (fig. 52); Xth tergum with basoventral margin produced into a triangular (fig. 52); gonocoxite, ventral view, with basomedian margin produced into a small, rounded process (fig. 54 ); basomedian branches with distal part slightly diverging (fig. 54) ........... H. ouaroua sp. n.

21. Xth tergum with four median pairs long, dark brown/blackish megasetae (figs. 83, 84) .........22

- Xth tergum without median megasetae, or if present, they are short, pale and oriented laterad (fig. 89) 23

22. IXth tergite with a rounded dorsal process (fig. 83); Xth tergal megasetae about $1.5 \times$ longer than the secondary branch of gonocoxite; Xth tergum about as long as gonocoxite

H. nigrospinosa sp. $\mathrm{n}$.

- IXth tergite without dorsal process (fig. 65); Xth tergal megasetae about as long as the secondary branch of gonocoxite; Xth tergum shorter than gonocoxite ............................ H. penicilla sp. n.

23. Xth tergum with dorsobasal megasetae (fig. 89)

- Xth tergum without dorsobasal megasetae (figs. 
$75,78)$ 25

24. IXth sternum anteriorly produced and pointed (fig. 89); Xth tergum with apical megasetae (fig. 89); Xth tergum with mediolateral short setae (fig. 89); gonocoxal primary branch spoonshaped (fig. 89) H. livida sp. n.

- IXth sternum anteriorly little produced, rounded; Xth tergum without apical megasetae; Xth tergum without mediolateral setae; gonocoxal primary branch shoe-shaped H. asymmetrica Ross

25. Xth tergum with row of lateral megasetae confined to median part of the segment (fig. 78); gonocoxal primary branch apex more than $3 \times$ wider than basal part (fig. 75) .H. patriciae sp. n.

- Xth tergum without megasetae on median part of the segment (fig. 110); gonocoxal primary branch apex about $2 \times$ wider than basal part (fig. 109)

26. Phallus with apical sclerous processes ............................ 26 nia Ross

- Phallus without apical sclerous processes (fig. 113) H. gibbsi sp. n.

27. Posterior wings with anal veins covered by small scaloid setae (fig. 12); fore leg without dorsal row of long blackish setae on tibia and tarsus; phallus without sclerous processes (fig. 16); gonocoxal primary and secondary branches diverging (fig. 15); basomedian branch of gonocoxite short (fig. 18) ..... H. koghiensis sp. n.

- Posterior wings without small scaloid setae on anal veins (fig. 67); fore leg with dorsal row of long, blackish setae distally on tibia and first tarsal segment (fig. 68); phallus with a pair of long sclerous processes (figs. 72, 73); gonocoxal primary and secondary branches about parallel (fig. 69); basomedian branch of gonocoxite long (fig. 71) H. tenuisa sp. n.

28. Xth tergum with three pairs of additional processes (fig. 20); postero-lateral part of IXth segment not produced posteriad (fig. 19); gono- coxite with a pair of additional processes (fig. 21) H. arma sp. n.

- Xth tergum with one pair of additional processes; postero-lateral part of IXth segment produced and curved mediad; gonocoxite without additional processes H. koumaca Ross

\section{ACKNOWLEDGEMENT}

I am grateful to Ms. Patricia Schefter (ROM), Dr. Oliver S. Flint Jr. (NMNH), Dr. John B. Ward (CM) and Dr. Ian M. Henderson for their kindness in letting me examine the unidentified Helicopsyche material of Royal Ontario Museum, Smithsonian Institution, Canterbury Museum and Ian M. Henderson Private Collection respectively.

\section{REFERENCES}

Johanson, K. A., 1995. World catalog of the Trichoptera family Helicopsychidae (Insecta). - Beaufortia 14: 101124.

Johanson, K. A., 1997. Zoogeography and diversity of the snail case caddisflies (Trichoptera: Helicopsychidae). - In R. W. Holzenthal \& O.S. Flint Jr. (eds): Proceedings of the 8th International Symposium on Trichoptera, Ohio Biological Survey, Columbia: 205-212.

Johanson, K. A., 1998. Phylogenetic and biogeographic analysis of the family Helicopsychidae (Insecta: Trichoptera). - Entomologica Scandinavica Supplement 53: $1-172$.

Johanson, K. A. \& P. W. Schefter, 1999. Taxonomic survey of the NEW CALEDONIAn Helicopsyche described by H. H. Ross (Trichoptera: Helicopsychidae). - Entomologica Scandinavica 29: 1-29.

Ross, H. H., 1975. A preliminary report on the Helicopsychidae (Trichoptera) of NEW CALEDONIA. - Cahiers ORSTOM, série Hydrobiologie 9: 67-80.

Received: 5 March 1999

Accepted: 28 April 1999 